\title{
Modulators of Kv3 Potassium Channels Rescue the Auditory Function of Fragile X Mice
}

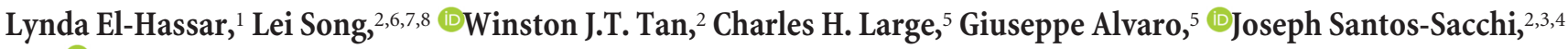 \\ and ${ }^{\circ}$ Leonard K. Kaczmarek ${ }^{1,4}$ \\ Departments of ${ }^{1}$ Pharmacology, ${ }^{2}$ Surgery, ${ }^{3}$ Neuroscience, ${ }^{4}$ Cellular and Molecular Physiology, Yale University School of Medicine, New Haven, Connecticut \\ 06520, ${ }^{5}$ Autifony Therapeutics Limited, Stevenage Bioscience Catalyst, Stevenage SG1 2FX, United Kingdom, ${ }^{6}$ Department of Otolaryngology-Head and \\ Neck Surgery, Shanghai Ninth People's Hospital, Shanghai Jiao Tong University School of Medicine, Shanghai 200011, P. R. China, ${ }^{7}$ Ear Institute, Shanghai \\ Jiao Tong University School of Medicine, Shanghai 200125, P.R. China, and ${ }^{8}$ Shanghai Key Laboratory of Translational Medicine on Ear and Nose Diseases, \\ Shanghai 200125, P. R. China
}

Fragile X syndrome (FXS) is characterized by hypersensitivity to sensory stimuli, including environmental sounds. We compared the auditory brainstem response (ABR) recorded in vivo in mice lacking the gene $\left(F m r 1^{-/ y}\right)$ for fragile $\mathrm{X}$ mental retardation protein (FMRP) with that in wild-type animals. We found that ABR wave I, which represents input from the auditory nerve, is reduced in $F m r 1^{-/ y}$ animals, but only at high sound levels. In contrast, wave IV, which represents the activity of auditory brainstem nuclei is enhanced at all sound levels, suggesting that loss of FMRP alters the central processing of auditory signals. Current-clamp recordings of neurons in the medial nucleus of the trapezoid body in the auditory brainstem revealed that, in contrast to neurons from wild-type animals, sustained depolarization triggers repetitive firing rather than a single action potential. In voltage-clamp recordings, $\mathrm{K}^{+}$currents that activate at positive potentials ("high-threshold" $\mathrm{K}^{+}$currents), which are required for high-frequency firing and are carried primarily by Kv3.1 channels, are elevated in $\mathrm{Fmrl}^{-/ y}$ mice, while $\mathrm{K}^{+}$currents that activate near the resting potential and inhibit repetitive firing are reduced. We therefore tested the effects of AUT2 [((4-(\{5-[(4R)-4-ethyl-2,5-dioxo-1-imidazolidinyl]-2-pyridinyl\}oxy)-2-(1-methylethyl) benzonitrile], a compound that modulates Kv3.1 channels. AUT2 reduced the high-threshold $\mathrm{K}^{+}$current and increased the low-threshold $\mathrm{K}^{+}$currents in neurons from $\mathrm{Fmrl}^{-/ y}$ animals by shifting the activation of the high-threshold current to more negative potentials. This reduced the firing rate and, in vivo, restored wave IV of the ABR. Our results from animals of both sexes suggest that the modulation of the Kv3.1 channel may have potential for the treatment of sensory hypersensitivity in patients with FXS.

Key words: auditory brainstem response; AUT2; fragile X; high- and low-threshold potassium channels; medial nucleus of the trapezoid body; potassium channels

Significance Statement

mRNA encoding the Kv3.1 potassium channel was one of the first described targets of the fragile $\mathrm{X}$ mental retardation protein (FMRP). Fragile $\mathrm{X}$ syndrome is caused by loss of FMRP and, in humans and mice, causes hypersensitivity to auditory stimuli. We found that components of the auditory brain response (ABR) corresponding to auditory brainstem activity are enhanced in mice lacking FMRP. This is accompanied by hyperexcitability and altered potassium currents in auditory brainstem neurons. Treatment with a drug that alters the voltage dependence of $\mathrm{Kv} 3.1$ channels normalizes the imbalance of potassium currents, as well as $\mathrm{ABR}$ responses in vivo, suggesting that such compounds may be effective in treating some symptoms of fragile $\mathrm{X}$ syndrome.

\section{Introduction}

Fragile X syndrome (FXS) is a genetic disease caused by a silencing mutation of the FMR1 gene. In the majority of cases, this is caused by an expansion of the CGG repeats in the promoter region of the FMR1 gene, which leads to a lack of fragile X mental retardation protein (FMRP; Oberlé et al., 1991; Verkerk et al., 1991). FMRP is a mRNA binding protein that controls the func-

C.H.L. is a director of Autifony Therapeutics Limited. G.A. is a full-time employee of Autifony Therapeutics Limited. We thank Dr. Nigel Bamford for support and use of electrophysiological equipment.

Correspondence should be addressed to Leonard K. Kaczmarek at leonard.kaczmarek@yale.edu.

https://doi.org/10.1523/JNEUROSCI.0839-18.2019

Copyright $\odot 2019$ the authors 
tion and expression level of a variety of proteins including several ion channels (Darnell et al., 2011). Patients with FXS experience multiple symptoms such as hypersensitivity to sensory stimuli, hyperactivity, susceptibility to seizures, intellectual disability, anxiety, and social and memory impairment (Garber et al., 2008; Chonchaiya et al., 2009). Some of these symptoms have been replicated in fragile $\mathrm{X}$ mice in which the gene for FMRP has been deleted (Fmr1 ${ }^{-1 y}$ mice; Michalon et al., 2012; Curia et al., 2013; Rotschafer and Razak, 2014; Myrick et al., 2015; Bostrom et al., 2016; Aloisi et al., 2017; Pyronneau et al., 2017; Sinclair et al., 2017). In humans, early intervention, such as drug treatment, speech therapy, schooling, and social integration, are believed to improve cognition in patients with FXS (Lozano et al., 2016). This offers hope that further effective treatments for fragile $\mathrm{X}$ symptoms will emerge if the appropriate targets for therapeutic agents can be identified.

One symptom that is relevant to this study is the hypersensitivity of patients with FXS to auditory stimuli (Arinami et al., 1988; Roberts et al., 2005). Physiological levels of sound evoke abnormal elevation of the cortical auditory response in patients with FXS (St Clair et al., 1987; Rojas et al., 2001; Castrén et al., 2003; Van der Molen et al., 2012), and ordinary environmental sounds can become unbearable for patients with FXS. In addition to this hypersensitivity to auditory stimuli, patients with fragile $\mathrm{X}$ syndrome have difficulties in discriminating the timing of auditory stimuli, which renders them unable to localize sounds in space (Hall et al., 2009; Rotschafer and Razak, 2014). Both the elevated cortical responses to sound stimuli and the deficits in temporal processing are likely to be influenced by alterations in subcortical networks such as those in the auditory brainstem that compute sound localization. These include the anteroventral cochlear nucleus (AVCN) and the medial nucleus of the trapezoid body (MNTB), as well as the medial and lateral superior olivary nuclei to which the AVCN and MNTB project. This conclusion is supported by the finding that the auditory brainstem response (ABR) recorded in vivo is altered in adult $\mathrm{Fmrl}^{-1 y}$ mice, and this may result, in part, from an alteration in the balance of excitation and inhibition (Rotschafer et al., 2015; Garcia-Pino et al., 2017; McCullagh et al., 2017).

The intrinsic excitability of neurons is determined by the ion channels they express. The mRNAs for several ion channels bind FMRP (Darnell et al., 2011), and in several cases the loss of FMRP has been demonstrated to alter levels of ion channel proteins in neurons (Brager and Johnston, 2014; Frick et al., 2017). Moreover, a subset of these ion channel proteins bind FMRP directly, altering the amplitude, gating, or trafficking of the channels (Brown et al., 2010; Zhang et al., 2012; Deng et al., 2013, 2019; Ferron et al., 2014; Myrick et al., 2015; Yang et al., 2018). Previous studies have demonstrated that currents corresponding to some of these ion channels are altered in the auditory brainstem MNTB neurons of $\mathrm{Fmrl}^{-/ y}$ mice (Brown et al., 2010; Strumbos et al., 2010b). We have now analyzed the effects of the loss of FMRP on the intrinsic excitability of auditory brainstem MNTB neurons in vitro and compared this to alterations in auditory brainstem responses in vivo, in $F m r 1^{-l y}$ and wild-type (WT) mice. We have also characterized the actions of a small molecule, AUT2 [((4(\{5-[(4R)-4-ethyl-2,5-dioxo-1-imidazolidinyl]-2-pyridinyl $\}$ oxy)2-(1-methylethyl) benzonitrile; Brown et al., 2016], which modulates Kv3.1 potassium channels, and found that this compound was able to normalize both the firing patterns of MNTB neurons and the ABR of $\mathrm{Fmrl}^{-1 y}$ mice.

\section{Materials and Methods}

AUT compound. AUT2 (Autifony Therapeutics) is a small molecule modulator of human and rodent Kv3.1 and Kv3.2 channels. Some of the electrophysiological actions of AUT2 have been described previously (Brown et al., 2016). AUT2 is a cell-permeant small molecule, which modulates human recombinant Kv3.1 channels by shifting the voltage dependence of activation and inactivation to negative potentials $\left(\mathrm{EC}_{50}\right.$, $0.9 \mu \mathrm{M}$; Brown et al., 2016). AUT2 (10 mM stock solution) was dissolved in DMSO $(0.1 \%)$, and the final concentration used in the recording chamber was $10 \mu \mathrm{M}$ for in vitro recordings. A $10 \mu \mathrm{M}$ concentration of AUT2 has previously been shown to strongly modulate the recombinant $\mathrm{Kv} 3.1$ channel, causing a $28 \mathrm{mV}$ leftward shift in the V1/2 of activation (Brown et al., 2016). For testing the effects of AUT2 on auditory brainstem response in vivo, we prepared a vehicle containing 12.5\% of Captisol, mixed with $0.5 \%$ HPMC (hydroxypropylmethylcellulose) $\mathrm{K} 15 \mathrm{M}$ and $0.5 \%$ Tween 80 in sterile water. The AUT2 drug suspension was then prepared by dissolving AUT2 compound in the vehicle solution, which was used at a final concentration of $30 \mathrm{mg} / \mathrm{kg}$ and dosed by the intraperitoneal route $20 \mathrm{~min}$ before testing. While formal pharmacokinetic studies have not been conducted with this compound in the mouse, a dose of $30 \mathrm{mg} / \mathrm{kg}$ AUT2 administered orally to rats gave brain concentrations of $\sim 3500 \mathrm{ng} / \mathrm{ml} 2 \mathrm{~h}$ after dosing (Autifony Therapeutics, unpublished data). Taking into account brain tissue binding, this is expected to be equivalent to a free brain concentration of $\sim 0.5 \mu \mathrm{M}$. The brain concentration of AUT2, $20 \mathrm{~min}$ after $30 \mathrm{mg} / \mathrm{kg}$, i.p., administration, might be expected to be in the range of $0.5-1 \mu \mathrm{M}$.

Electrophysiological recordings from MNTB brain slices. Both male and female WT (FVB.129P2-Pde6b ${ }^{+}$Tyr $^{c-c h} /$ Ant) and Fmr1 ${ }^{-1 y}$ (FVB.129P2Fmr $\left.1^{\mathrm{tm} 1 \mathrm{Cgr}} / \mathrm{J}\right)$ mice were purchased from The Jackson Laboratory. All data represent the mean \pm SE. The number of neurons or animals is represented by " $n$ " or " $N$ " respectively.

All procedures described followed National Institutes of Health guidelines outlined in Preparation and Maintenance of Higher Animals during Neuroscience Experiments (publication 91-3207). Procedures were approved by the Institutional Animal Care and Use Committee at the Yale University School of Medicine. The auditory brainstem including the MNTB was extracted from 15-d-old wild-type (Fvbn129) and Fmr1 ${ }^{-1 y}$ mice of either sex. Acute transverse slices of the auditory brainstem were cut to a thickness of $250 \mu \mathrm{m}$ using procedures described previously (Yang and Wang, 2006). Recordings were performed in a chamber continuously perfused $(1-2 \mathrm{ml} / \mathrm{min})$ with oxygenated and warmed (31$33^{\circ} \mathrm{C}$ ) artificial CSF containing the following (in $\mathrm{mm}$ ): $124 \mathrm{NaCl}, 2.5 \mathrm{KCl}$, $25 \mathrm{NaHCO} 3,1.25 \mathrm{NaH}_{2} \mathrm{PO}_{4}, 2 \mathrm{MgCl} 2,2 \mathrm{CaCl} 2$, and 10 glucose. Wholecell patch-clamp recordings were made from visualized MNTB neurons using an upright Zeiss Axioskop 2 FS microscope with differential interference contrast optics. Patch pipettes (3-5 M 2 ) were pulled from borosilicate glass tubing (outer diameter, $2.0 \mathrm{~mm}$; wall thickness, $0.5 \mathrm{~mm}$ ) and filled with the following intracellular solution (in $\mathrm{mm}$ ): $32.5 \mathrm{KCl}, 97.5$ K-gluconate, 5 EGTA, 10 HEPES, and $1 \mathrm{MgCl}_{2}$, pH 7.2 (Macica et al., 2003). Voltage-clamp recordings were made using EPC-7 (HEKA Elektronik) or Multiclamp 700B (Molecular Devices) amplifiers. Tetrodotoxin $(1 \mu \mathrm{M})$ and $\mathrm{CdCl}_{2}(20 \mu \mathrm{M})$ were used to suppress $\mathrm{Na}^{+}$- and $\mathrm{Ca}^{2+}$ activated $\mathrm{K}^{+}$channels, respectively. Current-clamp recordings were made in bridge mode using an SEC 05L amplifier (npi electronic). Neurons with resting potentials more positive than $-50 \mathrm{mV}$ were discarded, regardless of treatment. The junction potential was not corrected. Uncompensated series resistances were on average 13.12 $\pm 0.31 \mathrm{M} \Omega(n=77$ cells, $N=52$ cells). Series resistance was compensated at $50-70 \%$. Access resistance and holding current were continuously monitored for stability; $>20 \%$ variation led to a rejection of the cell.

Data acquisition and analysis were performed using software that was either custom written in the IGOR Pro programming environment (WaveMetrics) or using pCLAMP version 9.2 (Molecular Devices). Conductance values were obtained by dividing the current by the electrochemical driving force, as follows: $I_{K} /\left(V m-E_{K}\right)$, where $I_{K}$ is the $\mathrm{K}^{+}$ current, $V_{m}$ is the membrane potential and EK is the reversal potential for $\mathrm{K}^{+}$ions. For voltage dependence of activation experiments, normalized conductance-voltage plots were obtained by normalizing conductance 
(G) to that measured at $+60 \mathrm{mV}\left(G_{+60}\right)$ for each recording and fit using the sigmoidal function: $y=A_{2}+\left(A_{1}-A_{2}\right) /\left(1+e^{\left(x-x_{0}\right) / k}\right)$, where $A_{1}$ and $A_{2}$ represent the initial and final values of the $y$ abscise, respectively; $k$ is the slope factor; and $x_{0}$ is the half-maximal value. For the voltage dependence of inactivation, normalized conductance-voltage plots were fitted by normalizing currents to the maximum obtained by stepping from $-100 \mathrm{mV}$ and fitted using the same function. These fits were not used to calculate V1/2 values, which were instead determined for each cell by direct determination of the potential at which conductance was 0.5 of the maximal value at $+60 \mathrm{mV}$. In current-clamp recordings, input resistance was calculated by applying a train of three hyperpolarizing current pulses (250 pA, $300 \mathrm{~ms}$ duration, at $0.3 \mathrm{~Hz}$ ), and comparing the mean maximal voltage deflection during these pulses to the baseline membrane potential $20 \mathrm{~ms}$ before current injections.

$A B R$. Animals ( $15 \mathrm{~d}$ old) were anesthetized with $480 \mathrm{mg} / \mathrm{kg}$, i.p., chloral hydrate, and all recordings were conducted in a sound-attenuating chamber (Industrial Acoustics). A customized TDT3 system (TuckerDavis Technologies) was used for ABR recordings. Subdermal needle electrodes (Rochester Electro-Medical) were positioned at the vertex (active, noninverting), the infra-auricular mastoid region (reference, inverting), and the neck region (ground). Differentially recorded scalp potentials were bandpass filtered between 0.05 and $3 \mathrm{kHz}$ over a $15 \mathrm{~ms}$ epoch. A total of 400 trials was averaged for each waveform for each stimulus condition.

Symmetrically shaped tone bursts were $3 \mathrm{~ms}$ long ( $1 \mathrm{~ms}$ raised cosine on/off ramps and $1 \mathrm{~ms}$ plateau). All acoustic stimuli were delivered free field via a speaker (Part FF1 2021, Tucker-Davis Technologies) positioned $10 \mathrm{~cm}$ from the vertex. Stimulus levels were calibrated using a 0.5 inch condenser microphone (model 4016, ACO Pacific) positioned at the approximate location of the animal's head during recording sessions and are reported in decibels of sound pressure level (SPL; referenced to 20 $\mu \mathrm{Pa})$. Stimuli of alternating polarity were delivered at a rate of $\sim 20 / \mathrm{s}$. Tone burst responses were collected in half-octave steps ranging from 32 to $2.0 \mathrm{kHz}$. The effects of level were determined by decreasing stimulus intensity in 5 or $10 \mathrm{~dB}$ steps. A maximum stimulus level of $90 \mathrm{~dB}$ SPL was used first to avoid overstimulation. The ABR threshold was defined as the lowest intensity of sound level capable of evoking a reproducible, visually detectable response (Song et al., 2006). Latencies and amplitudes of the initial four ABR peaks were measured from sound stimuli delivered at a rate of $20 / \mathrm{s}$ and at a frequency of $11.3 \mathrm{kHz}$, one of the most sensitive frequency ranges of hearing in mice. The analysis was performed off-line in BioSig (BioSig Technologies) on traces with visible peaks by setting cursors at the maxima and minima of the peaks. Latency was defined as the time from the onset of the stimulus to the peak, while amplitude was measured by taking the mean of the $\Delta \mathrm{V}$ of the positive and negative deflections of the ABR wave (Tan et al., 2017).

Experimental design and statistical analysis. All data were collected from different littermates and used both males and females. Data analysis was performed using Igor, Clampfit, and BioSig software. For whole-cell voltage-clamp experiments, evoked currents were quantified by measuring the mean current between $50 \mathrm{~ms}$ after the onset of a test pulse and 50 $\mathrm{ms}$ before the end of the pulse. The interval between each pulse protocol ranged from 3 to $5 \mathrm{~min}$ in control conditions. When waiting for drugs to take effect, cells were held at resting membrane potentials for 10-15 min. The analyses used either a paired two-tailed $t$ test (for comparison between $\mathrm{Fmrl}^{-1 y}$ mice before and after AUT2 treatment) or unpaired twotailed $t$ test for comparison between wild-type and $\mathrm{Fmrl}^{-1 y}$ mice (with Welch's correction). In some cases, for example, when a comparison of ABR amplitude and/or latency with genotype (or with AUT2 treatment) across sound level intensity was performed, we used a two-way ANOVA that considered a full set of variances. Similarly, for data comparing the number of action potentials between genotypes across stimulus frequencies or the magnitude of potassium current between genotypes across membrane voltages, we performed a two-way ANOVA followed by a post hoc multiple comparison using Bonferroni-Dunn or Holm-Sidak method. A value of $p<0.05$ was considered significant for all tests. Statistical analysis was conducted using GraphPad Prism 8 and Origin software.

\section{Results}

\section{Loss of FMRP alters central processing of auditory information}

To investigate how loss of FMRP impacts the processing of auditory information early in development, we compared the in vivo $\mathrm{ABR}$ of 15-d-old wild-type and Fmr1 ${ }^{-/ y}$ mice, corresponding to 3-5 d after the onset of hearing. The ABR is characterized by a series of electrical waves, labeled as waves I to V (Jewett and Williston, 1971; Song et al., 2006), representing the progressive transfer of the auditory signal from the periphery to the CNS. Wave I represents the summated response from the spiral ganglion and auditory nerve, while waves II to $\mathrm{V}$ represent responses from the ascending auditory pathway (Akil et al., 2016).

We first determined that the threshold for detecting an electrophysiological response (ABR threshold) was not altered in $\mathrm{Fmrl}{ }^{-1 y}$ mice at all sound frequencies tested from 2 to $32 \mathrm{kHz}$ (Fig. 1A). ABRs were then recorded in response to an $11.3 \mathrm{kHz}$ stimulus lasting $3 \mathrm{~ms}$ at intensities up to $90 \mathrm{~dB}$ (Fig. 1B). A twoway ANOVA with mean comparison using Bonferroni's test was performed to compare the effects of genotype (WT or Fmr1 ${ }^{-1 y}$ mice) and of sound levels (from 40 to $90 \mathrm{~dB}$ ) on the amplitude of the ABR response. We found that the amplitude of wave I was significantly reduced in $F m r 1^{-l y}$ mice compared with WT mice $\left(F_{(1,353)}=15.44, p=0.0002\right)$. We also found a significant interaction effect between the genotype and sound level on the amplitude of wave $\mathrm{I}\left(F_{(10,353)}=2.4 ; p=0.01\right)$. When this analysis was followed by a simple test effect that corrected for multiple comparisons using Bonferroni-Dunn method, we found that the amplitude of wave I was significantly smaller in $F m r 1^{-/ y}$ animals at higher intensities of sound levels (Fig. $1 C$ : $85 \mathrm{~dB},{ }^{\star} p=0.002 ;{ }^{\star} 90$ $\mathrm{dB}, p=0.0009)$.

In contrast, the amplitude of wave IV, which reflects the synchronous activity of the auditory brainstem nuclei including the MNTB, was significantly enhanced in $F m r 1^{-1 y}$ mice $\left(F_{(1,301)}=\right.$ $30.33, p<0.0001)$. The intensity of sound level had a significant effect on the amplitude of wave IV $\left(F_{(10,301)}=10.20, p<0.0001\right)$, and the interaction of both genotype and sound levels also had an effect on the amplitude of wave IV $\left(F_{(10,301)}=2.23, p=0.01\right.$; Fig. $1 C)$. We thus performed a simple effects test and found that the amplitude of wave IV was significantly higher at 75, 80, 85, and 90 $\mathrm{dB}(p=0.0001$, Bonferroni-Dunn method $)$

We then analyzed the latency of each wave to investigate any potential changes in the rate of propagation through the nervous system. Although the latency of waves I appeared slightly prolonged in $\mathrm{Fmr1}^{-/ y}$ mice compared with wild-type mice, this difference was not statistically significant $\left(F_{(1,340)}=2.213, p=\right.$ 0.13 ). In addition, the latency of wave IV was not significantly different between WT and $F m r 1^{-/ y}$ mice $\left(F_{(10,285)}=0.3 p=\right.$ 0.98).

\section{Firing patterns of MNTB neurons are disrupted in Fmr1 ${ }^{-/ y}$ mice}

To determine whether the loss of FMRP alters the firing patterns of MNTB neurons, we performed in vitro recordings from principal neurons of the MNTB in brainstem slices from 15-d-old mice. We first used a whole-cell current-clamp configuration to record the response of cells to a series of sustained hyperpolarizing and depolarizing current pulses (200 ms square current pulses, -250 to $+350 \mathrm{pA})$. As has been found in previous studies (Wang et al., 1998a), we found that in response to a 250 or $350 \mathrm{pA}$ depolarizing current injection, MNTB neurons from wild-type mice fire only at the onset of the depolarization, and never fire more than one or two action potentials (Fig. $2 \mathrm{~A}$ ). In contrast, 
A

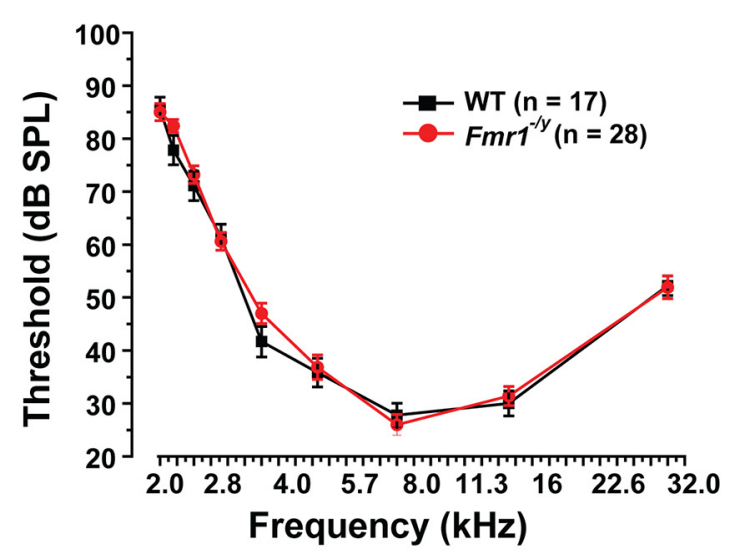

\section{Amplitude}

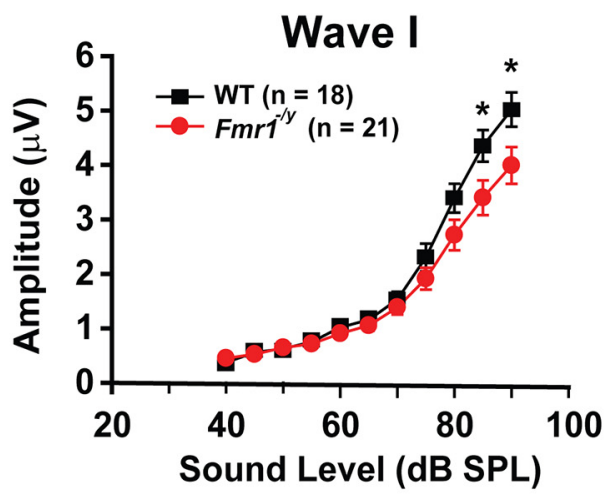

D Latency

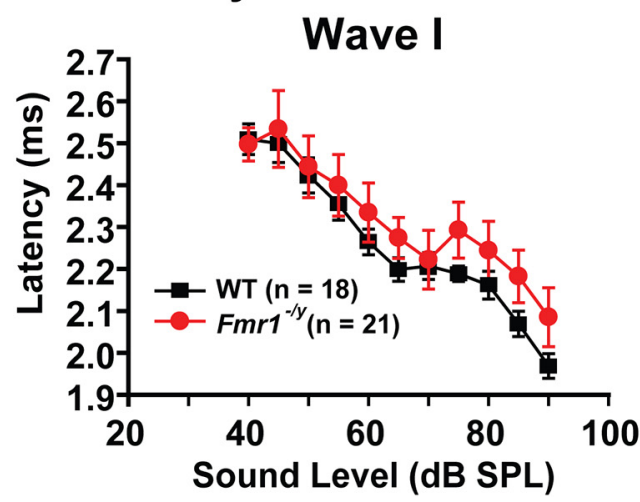

B

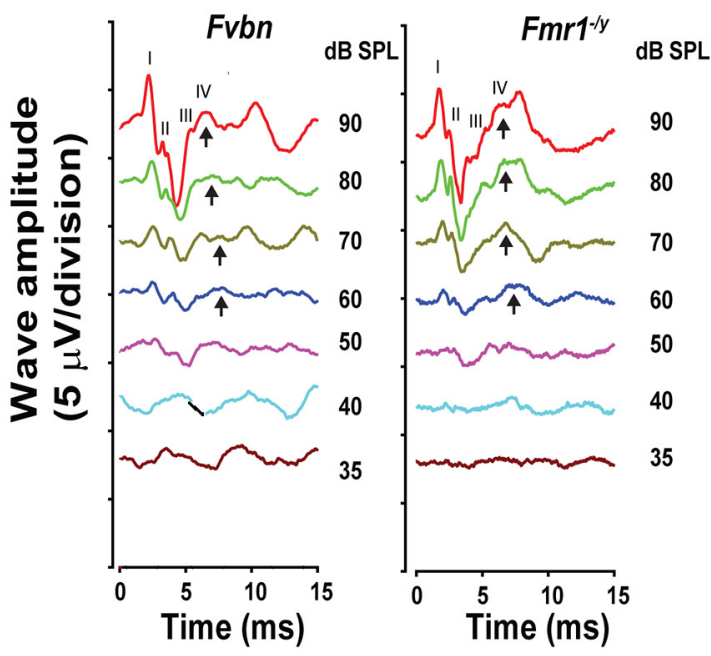

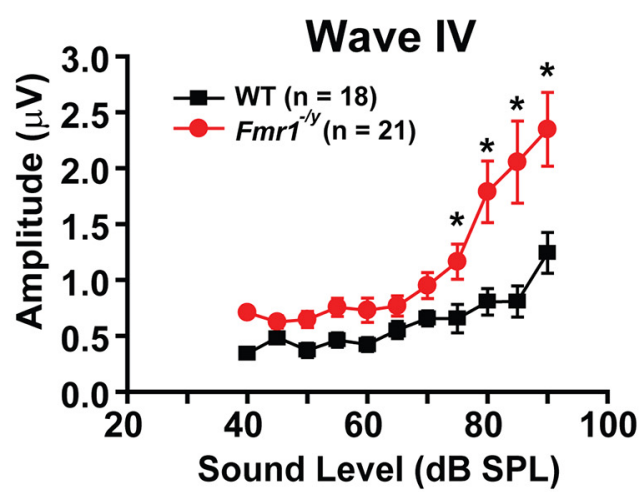

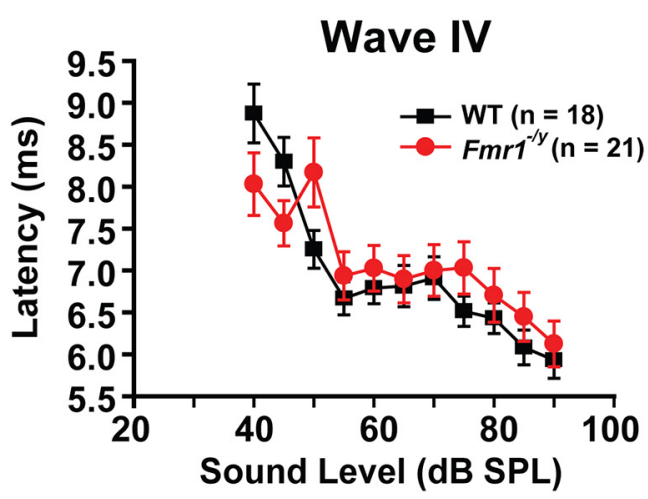

Figure 1. Loss of FMRP alters the central processing of auditory signals. $\boldsymbol{A}$, Plots of the $A B R$ thresholds for wild-type mice $(N=17$ animals $)$ and $F m r 1^{-/ y}$ mice $(N=28$ animals). $\boldsymbol{B}, A B R$ wave recordings from WT and $F m r 1^{-1 / y}$ mice stimulated at $11.3 \mathrm{kHz}$ at different sound levels (35-90 dB). Arrows indicate wave IV of the ABR response. $\boldsymbol{C}, \boldsymbol{D}$, Plots of the amplitudes ( $\boldsymbol{C}$ ) and latencies ( $\boldsymbol{D}$ ) of ABR waves I and IV as a function of sound levels ( $40-90 \mathrm{~dB}$ ). The magnitude of wave I is decreased for high sound levels $(p=0.0002)$ only, and there is a significant increase in wave IV amplitude in Fmr1 ${ }^{-1 / y}$ mice at most sound levels tested ( $p<0.0001$ ) without significant change in the ABR latencies. Error bars indicate the mean \pm SEM. In C, asterisks indicate statistical significance (two-way ANOVA followed by Bonferroni-Dunn post-test).

MNTB neurons from $F m r 1^{-/ y}$ mice fire repetitively throughout the sustained depolarizations (Fig. 2A,B). Overall, the number of action potentials evoked by the $200 \mathrm{~ms}, 250$ pA depolarizing current pulse was significantly greater in neurons from $F m r 1^{-1 y}$ mice $(5.82 \pm 1.48, n=27$ cells, $N=9$ animals; Fig. $2 A, B)$ than in those from wild-type animals $(0.33 \pm 0.11, n=18$ cells, $N=7$ animals; $p=0.002$, Student's unpaired $t$ test with Welch's correction; $t=$ 1.713 , df $=3.041)$.
The input resistances and resting membrane potentials of MNTB neurons from $F m r 1^{-/ y}$ mice $(88.70 \pm 5.42 \mathrm{M} \Omega$ and $-60.76 \pm 1.44 \mathrm{mV}, n=18, N=11$ ) were not different from those of wild-type mice $[90.65 \pm 9.67 \mathrm{M} \Omega$ and $-59.92 \pm 0.39$ $\mathrm{mV}, n=18, N=15 ; p=0.23$ for the input resistance comparison (Student's unpaired $t$ test with Welch's correction, $t=1.239$, $\mathrm{df}=22.76$ ); and $p=0.87$ for the resting membrane potential comparison (Student's unpaired $t$ test with Welch's correction 
A WT
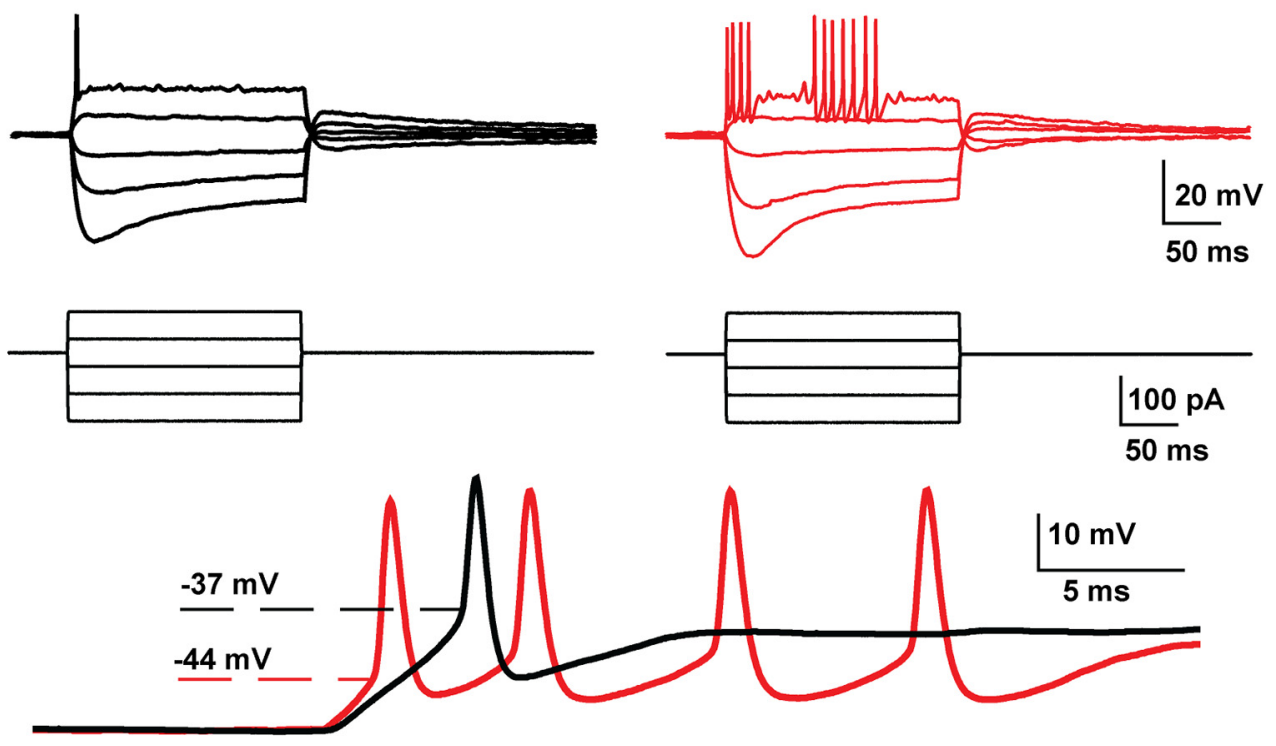

B

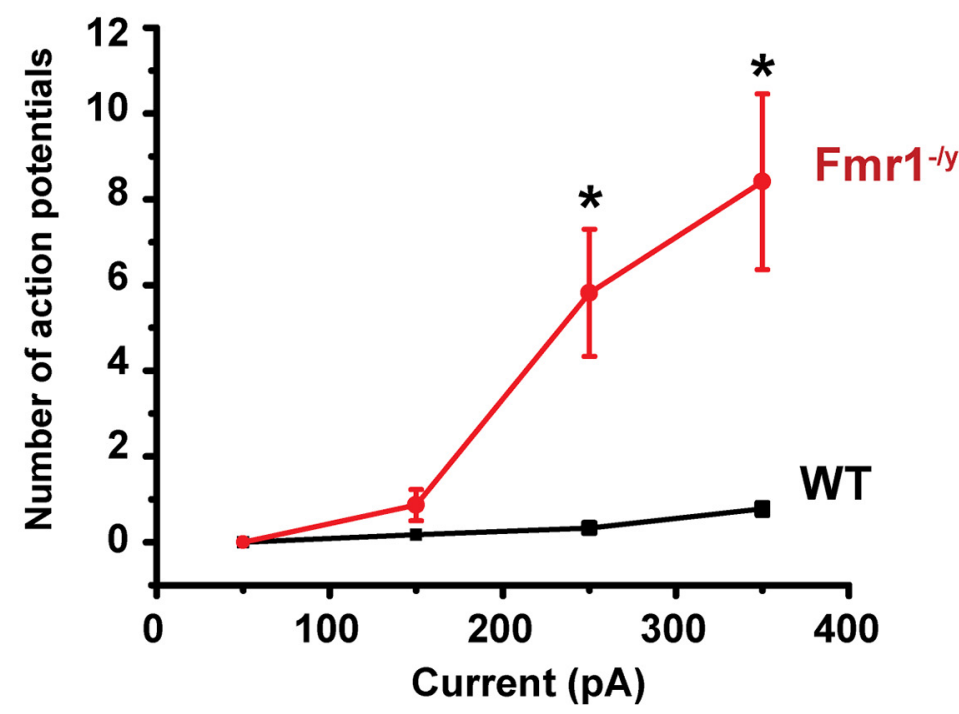

Figure 2. MNTB neurons from $F m r 1^{-1 y}$ mice are hyperexcitable. $A$, Current-clamp recordings of action potentials in response to a series of sustained hyperpolarizing and depolarizing current pulses (200 ms square current pulses, $-250 \mathrm{to}+350 \mathrm{pA})$. Note the repetitive firing and the shorter latency firing of MNTB neurons from Fmr ${ }^{-1 y}$ mice compared with the WT mice, which never fired more than one or two action potentials. $\boldsymbol{B}$, Group data showing a significant increase in number of action potentials evoked in neurons from $F m r 1^{-/ y}$ mice in response to currents of increasing amplitude (Asterisks indicate statistical significance. $p=0.002$, Student's unpaired $t$ test with Welch's correction).

Table 1. Electrical parameters of MNTB neurons from wild type and $F m r 1^{-/ y}$ animals

\begin{tabular}{llllll}
\hline Condition & $\begin{array}{l}\text { Input resistance } \\
(\mathrm{M} \Omega)\end{array}$ & $\begin{array}{l}\text { Resting membrane } \\
\text { potential }(\mathrm{mV})\end{array}$ & $\begin{array}{l}\text { Rheobase } \\
(\mathrm{pA})\end{array}$ & $\begin{array}{l}\text { First action potential } \\
\text { latency (ms) }\end{array}$ & $\begin{array}{l}\text { Spike } \\
\text { threshold }(\mathrm{mV})\end{array}$ \\
\hline Wild type & $90.65 \pm 9.67(18)$ & $-59.92 \pm 0.39(18)$ & $450 \pm 49.25(18)^{* *}$ & $3.67 \pm 0.24(18)$ & $-37.28 \pm 1.35(18)^{* *}$ \\
Fmr1 $^{-1 / y}$ & $88.70 \pm 5.42(18)$ & $-60.76 \pm 1.44(18)$ & $255.55 \pm 20.56(18)^{* *}$ & $3.48 \pm 0.32(18)$ & $-44.21 \pm 1.37(18)^{* *}$ \\
\hline${ }^{* * p}=0.001$ & & & & &
\end{tabular}

$(t=0.1649, \mathrm{df}=12.7)]$. We found, however, a significant difference in the spike threshold between the two groups of mice [wild-type mice: $-37.3 \pm 1.35 \mathrm{mV}, n=18, N=15$; vs Fmr1 ${ }^{-/ y}$ mice: $-44.2 \pm 1.37 \mathrm{mV}, n=18, N=11 ; p=0.001$, Student's unpaired $t$ test with Welch's correction $(t=3.59$, $\mathrm{df}=31.92)]$. This is consistent with a significant decrease of the rheobase from $450 \pm 49.25 \mathrm{pA}$ in wild-type mice to $255 \pm$ $20.56 \mathrm{pA}$ in $\mathrm{Fmrl}^{-1 y}$ mice (Table 1; $p=0.001$, Student's unpaired $t$ test, with Welch's correction; $t=3.643, \mathrm{df}=21.45$ ). We found, however, no statistical difference in action potential height between the wild-type mice $(43.51 \pm 3.73 \mathrm{mV}, n=$ $18, N=15)$ and the $F m r 1^{-1 y}$ mice $(42.11 \pm 2.57 \mathrm{mV}, n=18$, 
$N=11, p=0.8$; Student's unpaired $t$ test, with Welch's correction, $t=0.3085, \mathrm{df}=15.63$ ).

In response to high rates of stimulation, MNTB neurons are capable of locking their action potentials to stimuli at rates of up to several hundred hertz (Macica et al., 2003; Song et al., 2005; Kopp-Scheinpflug et al., 2011). We therefore compared the ability of MNTB neurons from wild-type and $\mathrm{Fmrl}^{-/ y}$ mice to follow repetitive stimuli of brief and subthreshold current pulses ( $1 \mathrm{nA}$, $0.3 \mathrm{~ms}, 20$ stimuli) applied at rates from 50 to $600 \mathrm{~Hz}$. Consistent with their enhanced excitability in response to sustained depolarization, we found that MNTB neurons from $\mathrm{Fmrl}^{-/ y}$ mice fired more action potentials compared with WT mice. For example, at $200 \mathrm{~Hz}$, the number of spikes elicited by a train of 20 stimuli was $14.38 \pm 1.43$ ( $n=10, N=9$ animals) in $F m r 1^{-1 y}$ mice compared with $8.66 \pm 1.92(n=13, N=10$ animals $)$ in wild-type mice ( $p=$ 0.04 , Student's unpaired $t$ test with Welch's correction; $t=2.381$, $\mathrm{df}=10.71$ ). A two-way ANOVA was further performed to examine changes in the number of spikes in relation to both variables: the genotype of animals (WT or $F m r 1^{-/ y}$ mice) and the frequency of stimulation. We found that the genotype had a stronger impact on the number of spikes $\left(F_{(1,75)}=16.88, p=0.0001\right.$; Fig. $\left.3 A, B\right)$. The stimulus frequency also had an effect on the number of evoked spikes $\left(F_{(3,75)}=2.81, p=0.04\right)$, but no significant interaction effect was found between the genotype and the stimulus frequency on the number of action potentials $\left(F_{(3,75)}=2.81, p=\right.$ $0.3)$. Post hoc tests that corrected for multiple comparisons showed that this increase in spike number in $\mathrm{Fmrl}^{-/ y}$ mice was significant for 50, 200, and $400 \mathrm{~Hz}(p=0.0005, p=0.04, p=$ 0.04 ) but not for $600 \mathrm{~Hz}$ ( $p=0.5$, Holm-Sidak method; Fig. $3 B$, asterisk).

\section{Multiple potassium currents are altered in MNTB neurons of $\mathrm{Fmrl}^{-1 /}$ mice.}

Several different types of voltage-dependent $\mathrm{K}^{+}$currents have been described in MNTB neurons. Some of these activate only at positive potentials and contribute primarily to the rapid repolarization of action potentials. These include currents attributed to the Kv3.1 and Kv2.2 channels (Macica et al., 2003; Steinert et al., 2011). Several other components of $\mathrm{K}^{+}$current activate near the resting potential and are required to maintain accurate temporal locking of action potentials to incoming stimuli. These include subunits of the Kv1, Kv11, and $\mathrm{K}_{\mathrm{Na}}$ subfamilies (Brew and Forsythe, 1995; Grigg et al., 2000; Dodson et al., 2002; Yang et al., 2007; Hardman and Forsythe, 2009; Mathews et al., 2010). To evaluate the effect of loss of FMRP on intrinsic excitability, we performed voltage-clamp experiments using protocols that differentiate between these two components of current in postnatal day 15 wild-type and $F m r 1^{-1 y}$ mice. Because several $\mathrm{K}^{+}$subunits have a tonotopic distribution in the MNTB (Li et al., 2001; Bhattacharjee et al., 2002, 2005; Brew and Forsythe, 2005; Strumbos et al., 2010a), we confined our recordings to cells in the lateral region of the MNTB.

We first recorded $\mathrm{K}^{+}$currents that activate at positive potentials by holding the membrane potential at $-40 \mathrm{mV}$ for $2 \mathrm{~min}$ before applying test pulses between -30 and $+60 \mathrm{mV}$ in $10 \mathrm{mV}$ increments (Fig. 4A). This holding potential causes the inactivation of most components of $\mathrm{K}^{+}$current that activate at more negative potentials, and $80-90 \%$ of the current evoked under these conditions represents the Kv3.1 current (Wang et al., 1998a; Macica et al., 2003). The amplitude of these currents at $+60 \mathrm{mV}$, which we will term "high-threshold" $\mathrm{K}^{+}$currents, was significantly higher in MNTB neurons from $\mathrm{Fmrl}^{-1 y}$ mice than in wildtype mice (Figs. $4 A, 5.90 \pm 0.40$ vs $3.99 \pm 0.66 \mathrm{nA}$, respectively, $p=0.02$; Student's unpaired $t$ test with Welch's correction: $t=$ $2.493, \mathrm{df}=14.87)$. A two-way ANOVA test revealed that both the genotype $\left(F_{(1,150)}=22.02, p<0.0001\right)$ and the membrane voltage $\left(F_{(9,150)}=45.54, p<0.0001\right)$ had a significant impact on the magnitude of high-threshold $\mathrm{K}^{+}$currents. Using a post hoc test that corrected for multiple comparisons, we found that the highthreshold $\mathrm{K}^{+}$currents were significantly increased in neurons from $F m r 1^{-/ y}$ mice at $40 \mathrm{mV}(p=0.01), 50 \mathrm{mV}(p=0.003)$, and $60 \mathrm{mV}(p=0.0007$; Fig. $4 A)$.

When the normalized conductance was plotted as a function of membrane voltage (Fig. 4A, right), we found no significant change in the conductance between WT and $\mathrm{Fmrl}^{-1 y}$ groups of mice. The half-activation potential $\left(\mathrm{V}_{1 / 2 \text { max }}\right)$ for the WT group was $-1.05 \pm 3.8(n=9, N=7)$ compared with $6.25 \pm 2.2 \mathrm{mV}$ in the Fmr1 $1^{-/ y}$ group ( $p=0.16, n=7, N=7$; Student's unpaired $t$ test with Welch's correction: $t=1.47, \mathrm{df}=12.94)$.

For the second protocol, the membrane potential was held at $-80 \mathrm{mV}$, and currents were evoked by potentials between -70 to $+60 \mathrm{mV}$ in $10 \mathrm{mV}$ increments. This evokes currents that activate near the resting potential and action potential threshold ( -60 to $-20 \mathrm{mV}$, low-threshold currents) as well as the high-threshold $\mathrm{K}^{+}$currents (Fig. 4B). Under these conditions, the currents recorded at $+60 \mathrm{mV}$ were significantly lower in MNTB neurons from $F m r 1^{-1 y}$ mice: $7.71 \pm 0.31 \mathrm{nA}(n=7, N=7$ animals $)$ than in those from wild-type mice vs $9.51 \pm 0.47 \mathrm{nA}(n=9, N=7$ animals, $p=0.007$, Student's unpaired $t$ test with Welch's correction: $t=3.535, \mathrm{df}=8.506$ ). Additional two-way ANOVA revealed a significant main effect of the genotype on the amplitude of low-threshold $\mathrm{K}^{+}$current $\left(F_{(2,139)}=56.30, p<0.0001\right)$. Using a post hoc test that corrected for multiple comparisons, we found that the low-threshold $\mathrm{K}^{+}$currents were significantly decreased in $\mathrm{Fmrl}^{-/ y}$ mice at membrane voltages from -10 to +60 $\mathrm{mV}(-10 \mathrm{mV}, p=0.006 ; 0 \mathrm{mV}: p=0.0005 ; 10 \mathrm{mV}: p=0.00002$; $20-50 \mathrm{mV}: p<0.0001 ; 60 \mathrm{mV}: p<0.0001$; Fig. $4 B)$.

When the normalized conductance was plotted as a function of membrane voltage (Fig. $4 B$ ), there was a significant decrease in the conductance in the Fmr1 ${ }^{-/ y}$ group of mice. The $\mathrm{V}_{1 / 2 \max }$ for the WT group was $-34.15 \pm 1.4 \mathrm{mV}$ compared with $-20.12 \pm$ $1.23 \mathrm{mV}$ in the $F m r 1^{-1 y}$ group ( $p=0.01$, Student's unpaired $t$ test with Welch's correction; $t=5.88, \mathrm{df}=6.99$ ).

These findings indicate that the high-threshold and lowthreshold $\mathrm{K}^{+}$currents are altered in opposite directions by loss of FMRP. Both of these changes are consistent with the increased excitability of MNTB neurons in $F m r 1^{-y}$ mice. Increased Kv3.1like high-threshold currents increase the ability of neurons to fire at high rates, while reduced low-threshold $\mathrm{K}^{+}$currents, which dominate total current in steps from $-80 \mathrm{mV}$, lower the threshold for action potentials and promote repetitive firing (Gan and Kaczmarek, 1998; Rudy and McBain, 2001; Zhang et al., 2012).

\section{Actions of the Kv3.1 channel modulator AUT2 on $\mathrm{K}^{+}$ currents in MNTB neurons from $\mathrm{Fmrl}^{-1 /}$ mice}

AUT2 is an imidazolidinedione derivative that modulates Kv3.1 channels (Brown et al., 2016; Fig. 5A). In mammalian cells transfected with human Kv3.1 channels, AUT2 shifts the voltage dependence of activation toward more negative potentials. This may cause Kv3.1 channels to activate at potentials that normally only activate low-threshold $\mathrm{K}^{+}$channels. In addition, AUT2 also shifts the voltage dependence of steady-state inactivation to more negative potentials, reducing the amount of current that can be activated by depolarization to positive potentials. We investigated the effects of AUT2 on the high- and low-threshold components of current in MNTB neurons of Fmr1 ${ }^{-/ y}$ mice. 
A

\section{WT}

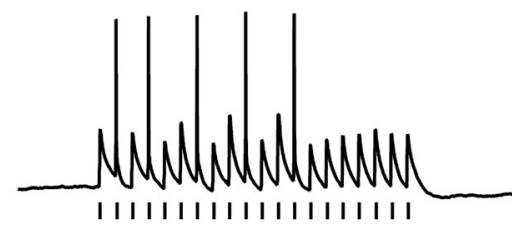

\section{$\mathrm{Fmr1}^{-/ \mathrm{y}}$}

\section{$50 \mathrm{~Hz}$}

$20 \mathrm{mV}$

$100 \mathrm{~ms}$

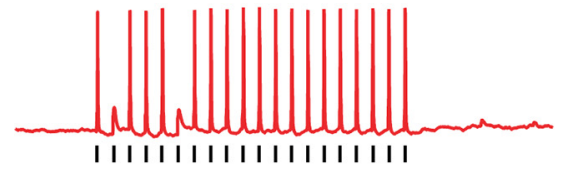

$200 \mathrm{~Hz}$

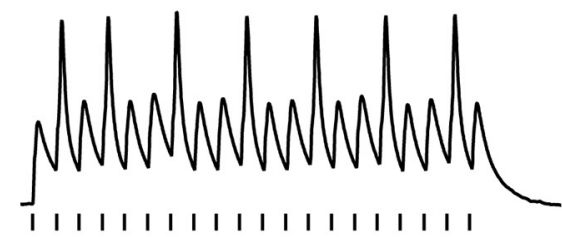

$10 \mathrm{mV}$

$25 \mathrm{~ms}$

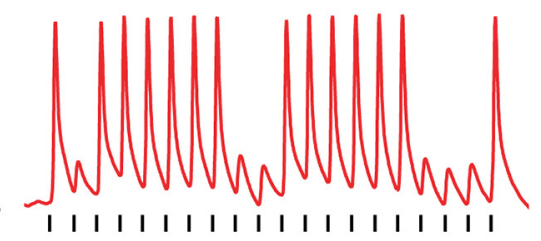

$400 \mathrm{~Hz}$

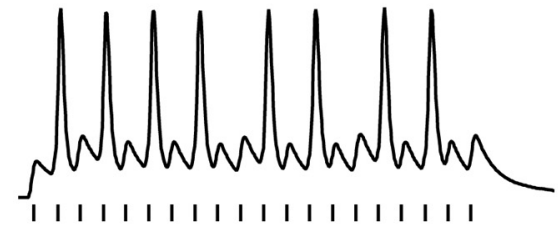

$20 \mathrm{mV}$
$10 \mathrm{~ms}$
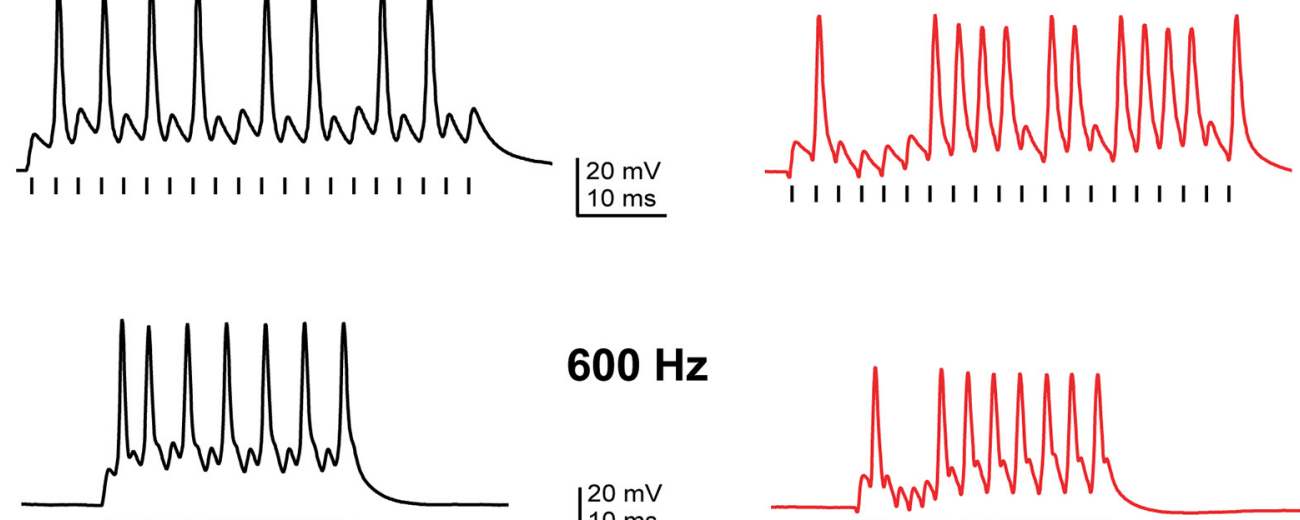

$600 \mathrm{~Hz}$

IIIIIIIIIIIIIIIIII

$20 \mathrm{mV}$
$10 \mathrm{~ms}$

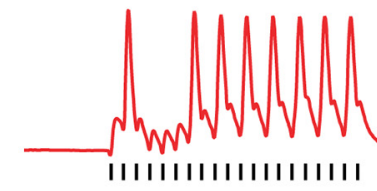

\section{B}

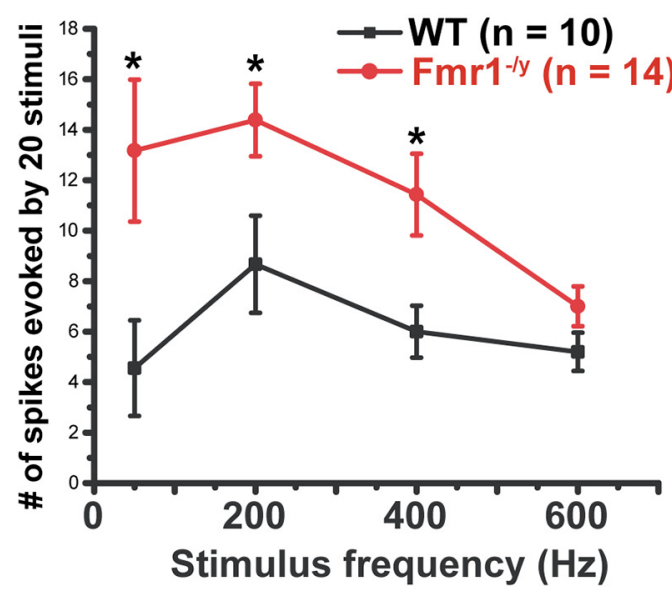

Figure 3. MNTB neurons from $F m r 1^{-1 /}$ mice fire more action potentials in response to repetitive stimulation. $A$, Current-clamp recordings of action potentials in response to repetitive stimulation with brief current pulses $\left(1 \mathrm{nA}, 0.3 \mathrm{~ms}, 20\right.$ stimuli) applied at rates from 50 to $600 \mathrm{~Hz}$. B, Group data showing that MNTB neurons from Fmr ${ }^{-1 /}$ mice fire more action potentials at all stimulus frequencies up to $400 \mathrm{~Hz}$. Asterisks indicate significant differences (two-way ANOVA followed by Holm-Sidak post-test). 
A

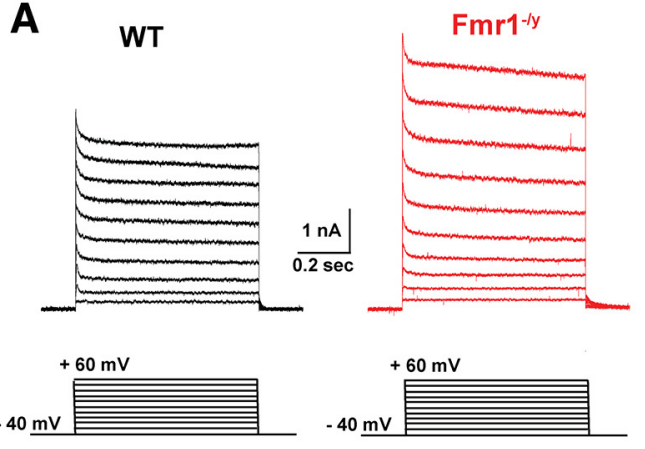

B

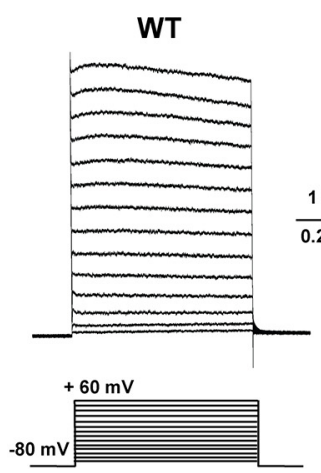

Fmr1-1y

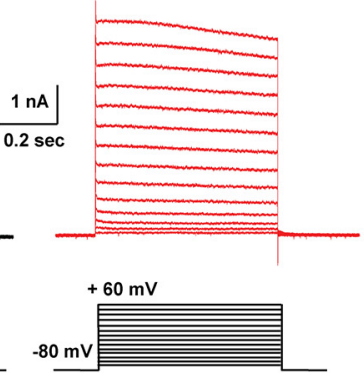

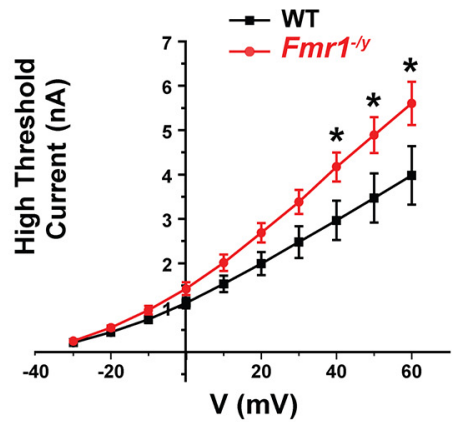

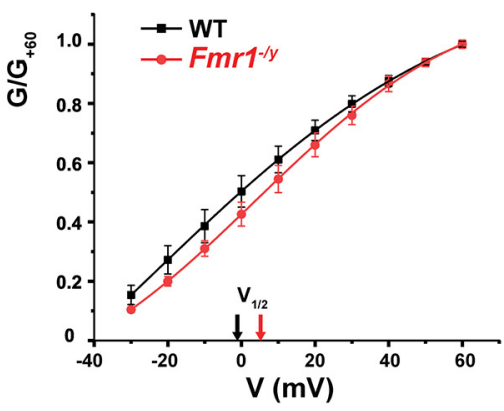

Figure 4. High- and low-threshold potassium currents are altered in MNTB neurons of $F m r 1^{-1 / y}$ mice. $\boldsymbol{A}$, Representative whole-cell patch-clamp recordings of high-threshold potassium current evoked by holding the membrane potential at $-40 \mathrm{mV}$ for 2 min before stepping to test potentials between -30 and $+60 \mathrm{mV}$ in $10 \mathrm{mV}$ increments. Middle, Plot shows that the amplitude of high-potassium current was significantly higher in MNTB neurons from $F m r 1^{-1 y}$ mice compared with wild-type mice (two-way ANOVA, $p<0.0001$ ). Right, Plot shows the corresponding normalized conductance that was not significantly $(p=0.16)$ different between WT and $F m r 1^{-1 / y}$ mice. $\boldsymbol{B}$, Representative whole-cell patch-clamp recordings of low-threshold potassium current by holding the membrane potential at $-80 \mathrm{mV}$ before stepping to test potentials from -70 to $+60 \mathrm{mV}$ in $10 \mathrm{mV}$ increments. Middle, Plots show that the peak amplitude of low-potassium current was significantly reduced in $\mathrm{Fmr}^{-1 y}$ mice compared with WT mice $\left(p<0.0001\right.$, two-way ANOVA). Plot on the right shows a significant shift in voltage dependence of the low-threshold $\mathrm{K}^{+}$ conductance in $F m r 1^{-1 / y}$ mice ( $p=0.01$, Student's unpaired $t$ test with Welch's correction). In the $I-V$ plots, asterisks indicate statistical significance in post-test results for multiple comparisons (Holm-Sidak method).

Application of AUT2 reduced the amplitude of the highthreshold component of currents that could be evoked from a holding potential of $-40 \mathrm{mV}$ to a test potential of $+60 \mathrm{mV}$ in MNTB neurons from $\mathrm{Fmrl}^{-/ y}$ mice. At $60 \mathrm{mV}$, the amplitude of the high-threshold potassium currents decreased from $4.82 \pm$ 0.54 to $2.24 \pm 0.22 \mathrm{nA}(n=4, N=4$ animals, $p=0.0006$, Student's paired $t$ test; Fig. 5A). Using a two-way ANOVA with post hoc correction for multiple comparisons, we found that AUT2 had a main effect on high-threshold current $\left(F_{(1,130)}=\right.$ 54.66, $p<0.0001)$. Because we found a significant interaction between AUT2 treatment and membrane voltage on the amplitude of high-threshold potassium currents $\left(F_{(9,130)}=3.20, p=\right.$ 0.001 ), we then performed a simple effects test and found that the high-threshold $\mathrm{K}^{+}$currents recorded in $\mathrm{Fmrl}^{-/ y}$ mice were significantly decreased by AUT2 treatment at membrane voltages from 20 to $60 \mathrm{mV}(20 \mathrm{mV}: p=0.01 ; 30 \mathrm{mV}: p=0.002 ; 40 \mathrm{mV}$ : $p=0.0001 ; 50$ and $60 \mathrm{mV} ; p<0.0001$; Fig. $5 A$ ).

When the normalized conductance was plotted as a function of membrane voltage (Fig. 5A), we found no significant change in voltage dependence after the addition of AUT2. The $V_{1 / 2 \text { max }}$ for the $F m r 1^{-/ y}$ group of mice was $0.67 \pm 3.59 \mathrm{mV}$ compared with $-2.53 \pm 5.72 \mathrm{mV}$ with AUT2 treatment $(p=0.84, n=4, N=4$ animals; Student's paired $t$ test, $t=0.2, \mathrm{df}=6$ ).

When the holding potential was maintained at $-80 \mathrm{mV}$, allowing for evaluation of combined low-threshold and highthreshold components of evoked $\mathrm{K}^{+}$currents, AUT2 produced a significant increase in current. For example, the current at +60 $\mathrm{mV}$ was increased from $6.64 \pm 0.57 \mathrm{nA}$ in MNTB neurons from $F m r 1^{-/ y}$ mice to $8.43 \pm 0.4 \mathrm{nA}(p=0.031, n=4, N=4$ animals Student's paired $t$ test; Fig. $5 B$ ). Using a two-way ANOVA with post hoc correction for multiple comparisons, we found that AUT2 had a main effect on low-threshold current $\left(F_{(2,209)}=\right.$ $61.65, p<0.0001)$. Because we found a significant interaction between the drug treatment and membrane voltage $\left(F_{(26,209)}=\right.$ $2.14, p=0.001$ ), we performed a simple effects test and found that that the increase of low-threshold potassium current by AUT2 was significant at membrane voltages from -20 to +60 $\mathrm{mV}(-20 \mathrm{mV}: p=0.01 ;-10 \mathrm{mV}: p=0.002 ; 0 \mathrm{mV}: p=0.0004$; $10-60 \mathrm{mV}: p<0.0001$; Fig. $5 B)$.

The voltage dependence of the low-threshold currents was also altered by AUT2. When the normalized conductance was plotted as a function of membrane voltage (Fig. $5 B$ ), we found a significant shift of the $\mathrm{V}_{1 / 2 \max }$ toward hyperpolarized potentials after AUT2 treatment. Values of $V_{1 / 2 \text { max }}$ shifted from $8.42 \pm 3.33$ $\mathrm{mV}$ before AUT2 to $-3.82 \pm 0.65 \mathrm{mV}$ after AUT2 application ( $p=0.004, n=4, N=4$ animals; Student's paired $t$ test, $t=5$; $\mathrm{df}=5)$.

We have previously described that application of AUT2 alters also the voltage dependence of inactivation of Kv3.1 channels when expressed in mammalian cells (Brown et al., 2016). To test further whether the same concentration of AUT2 used previously $(10 \mu \mathrm{M})$ can also change the inactivation curve of the high- 

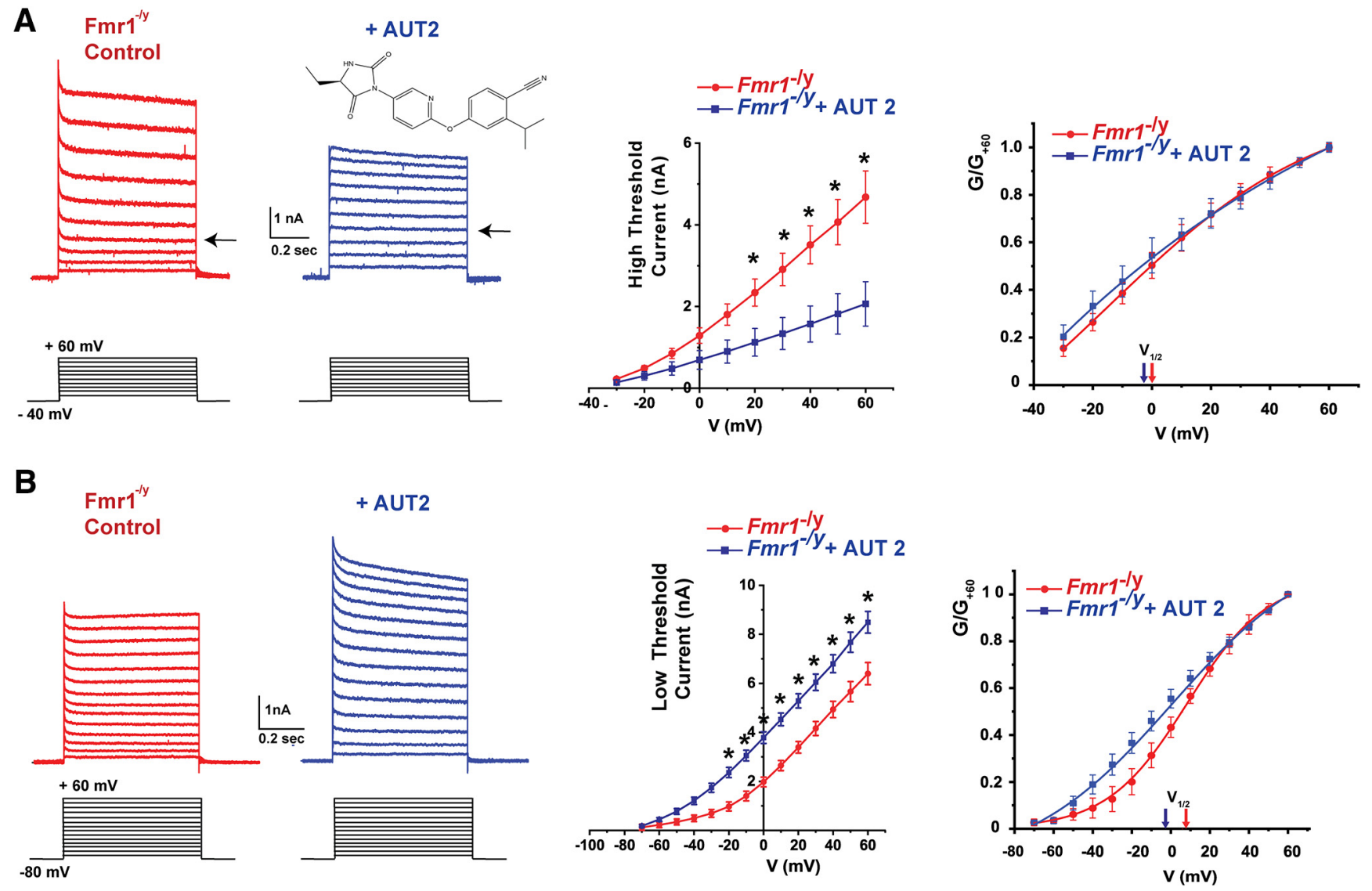

Figure 5. AUT2 decreases high-threshold potassium current and increases low-threshold potassium current of MNTB neurons from $F m r 1^{-1 / y}$ mice. $A$, Representative traces of high-threshold potassium current evoked by holding the membrane potential at $-40 \mathrm{mV}$ and stepping to test potentials from -30 and $+60 \mathrm{mV}$ in $10 \mathrm{mV}$ increments before and after the addition of $10 \mu \mathrm{m} \mathrm{AUT2}$. The chemical structure of AUT2 is shown above the right-hand current traces. Middle, Group data for the effects of AUT2 on current amplitude at different voltages. Right, group data for conductance-voltage relations normalized to maximal value at $+60 \mathrm{mV}\left(\mathrm{G} / \mathrm{G}_{+60}\right)$, indicating that AUT2 did not produce a significant change of the voltage-dependent activation of high-threshold potassium currents. $\boldsymbol{B}$, Representative whole-cell patch-clamp recordings of low-threshold potassium current evoked by holding the membrane potential at $-80 \mathrm{mV}$ and applying test potentials from -70 to $+60 \mathrm{mV}$ in $10 \mathrm{mV}$ increments before and after addition of AUT2 (10 $\mu \mathrm{m})$. Panels at center and right show group data for current amplitudes and conductance-voltage relations, demonstrating that AUT2 significantly increased the low-threshold potassium currents in $\mathrm{Fmr}^{-1 y}$ mice. Asterisks in $\boldsymbol{A}$ and $\boldsymbol{B}$ indicate statistical significance in post-test results of the simple effect test for multiple comparison (Holm-Sidak method).
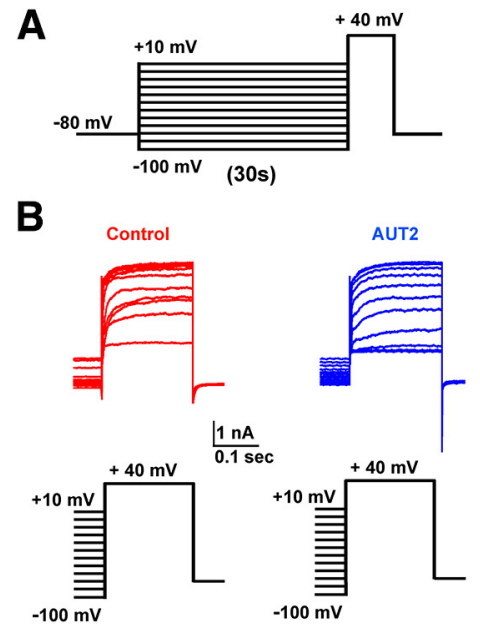

C

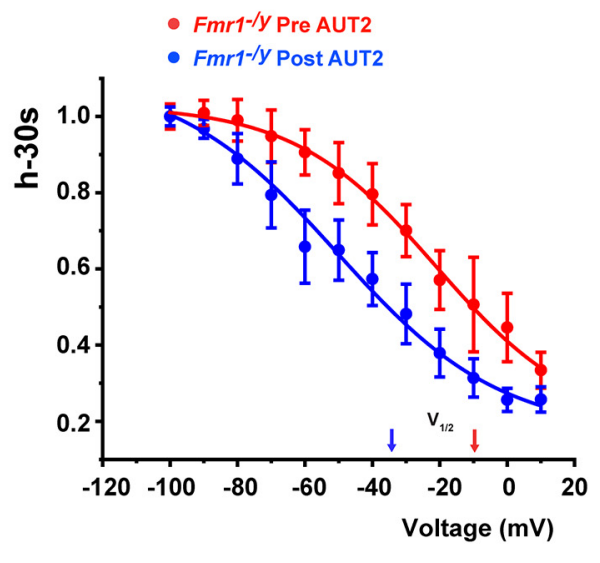

D

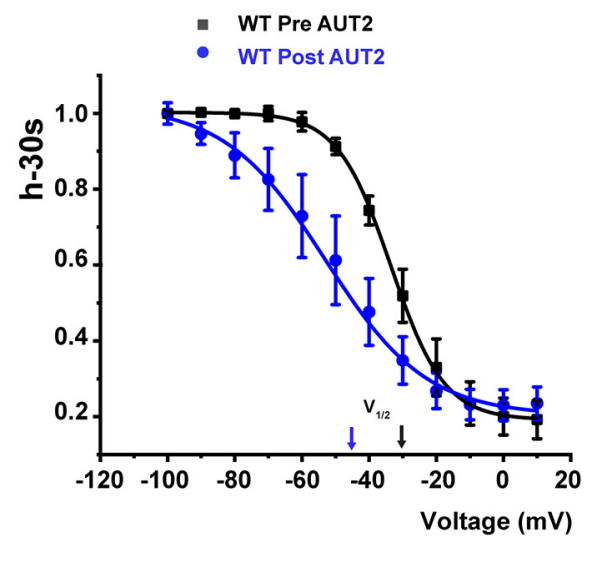

Figure 6. Addition of AUT2 produces a left shift in the voltage dependence of inactivation of high-threshold potassium currents in wild-type and $F \mathrm{mr} 1^{-1 / y}$ mice. $\boldsymbol{A}$, Standard voltage-clamp protocol to assess the inactivation of $\mathrm{K}^{+}$currents. Cells were held at potentials between -100 and $+10 \mathrm{mV}$ for 30 s before a test pulse to $+40 \mathrm{mV}$. $\boldsymbol{B}$, Representative traces of the outward current recorded in neurons from $F m 1^{-1 /}$ mice at a test potential of $+40 \mathrm{mV}$ before and after AUT2 $(10 \mu \mathrm{M})$. C, D, Plots of steady-state inactivation as a function of a $30 \mathrm{~s}$ prepulse to potentials between -100 and $+10 \mathrm{mV} \mathrm{in} \mathrm{Fmr1}{ }^{-1 \mathrm{y}}(\boldsymbol{C})$ and WT (D) mice. 
A WT
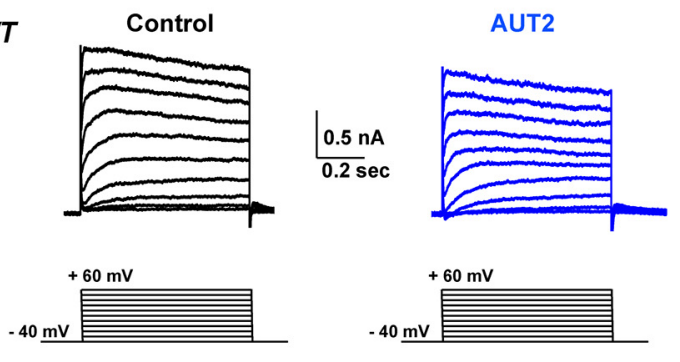

B

WT
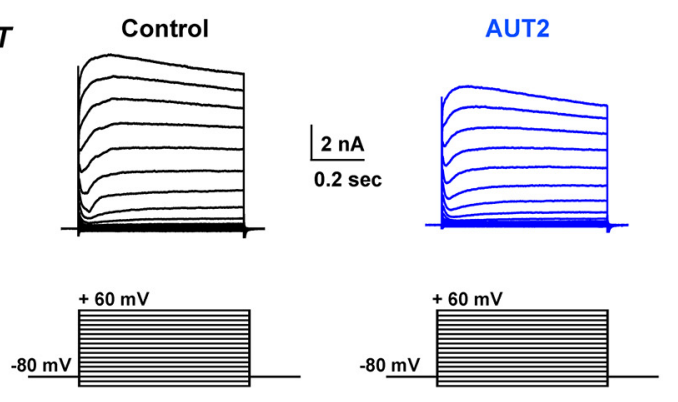

C
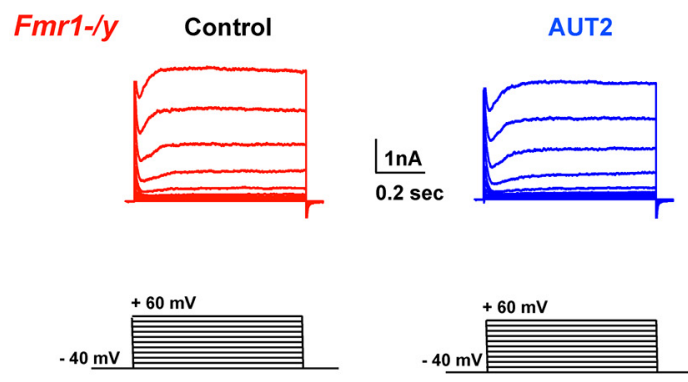

D
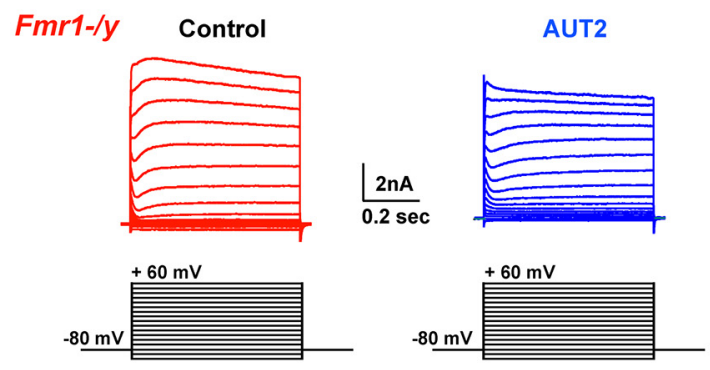
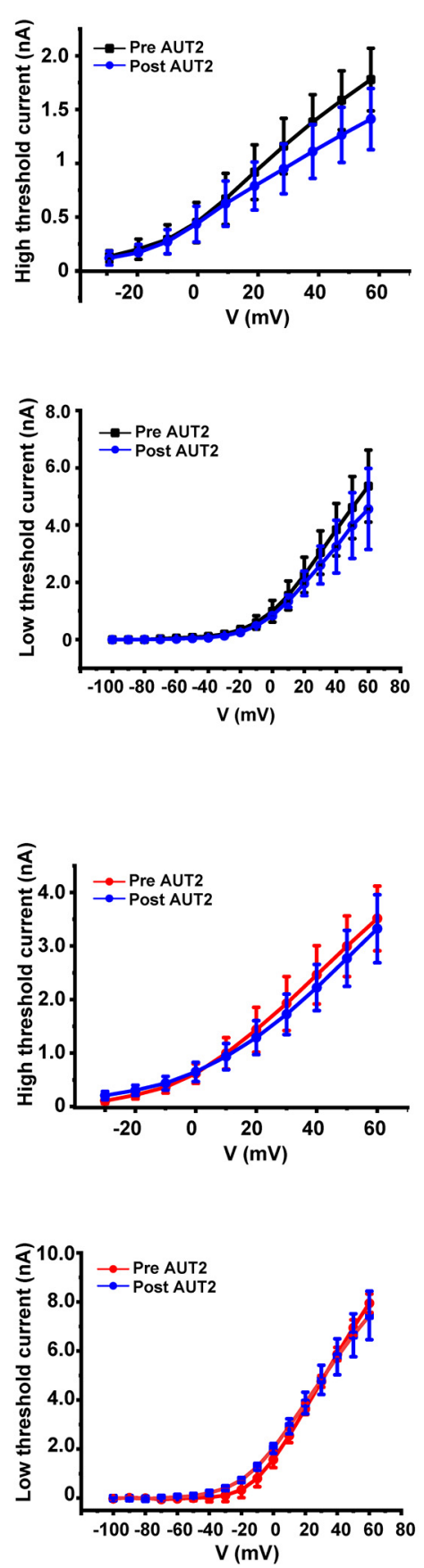
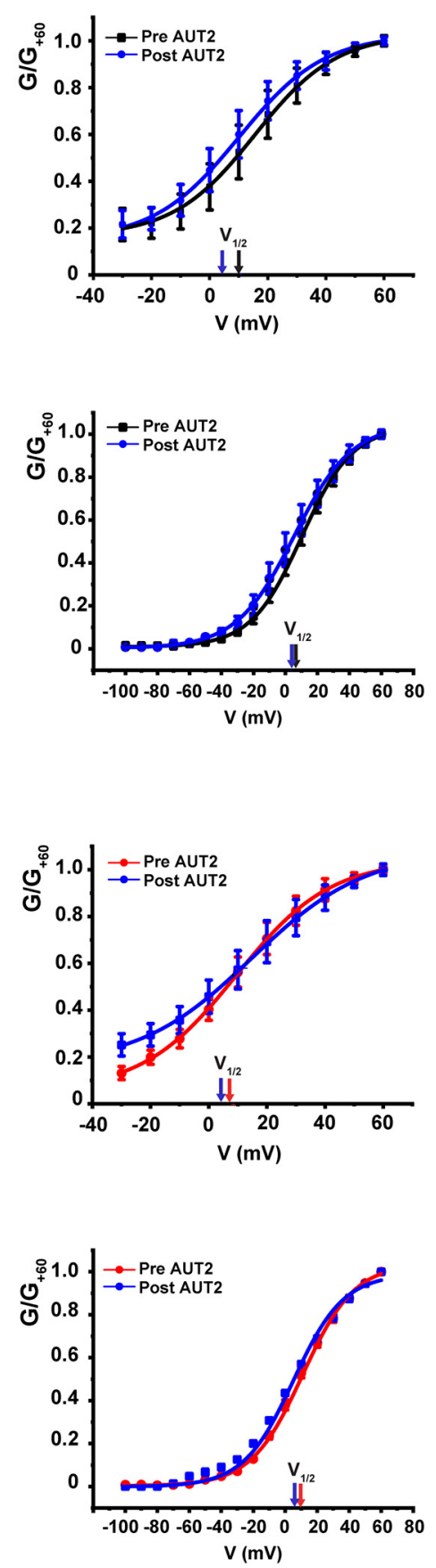

Figure 7. AUT2 fails to alter high- and low-threshold $\mathrm{K}^{+}$currents in the presence of the Kv3 channel blocker TEA. $\boldsymbol{A}-\boldsymbol{D}$, Voltage-clamp recordings of the high-threshold $(\boldsymbol{A}, \boldsymbol{C})$ and low-threshold $(\boldsymbol{B}, \boldsymbol{D})$ potassium currents in wild-type and in $F m r^{-1 /}$ mice. Panels on the right show the current-voltage and the conductance-voltage (normalized to maximal value at $\left.+60 \mathrm{mV} ; G / G_{+60}\right)$ curves for high- and low-threshold $\mathrm{K}^{+}$currents before and after AUT2, in the presence of the Kv3 channels blocker TEA (1 mM). AUT2 failed to alter the magnitude and the conductance of both high- and low-threshold potassium currents in these conditions.

threshold of $\mathrm{K}^{+}$currents in MNTB neurons, we used a standard protocol to assess the inactivation of $\mathrm{K}^{+}$currents. Neurons were held at potentials between -100 and $+10 \mathrm{mV}$ for $30 \mathrm{~s}$ before a test pulse to $+40 \mathrm{mV}$, before and after the application of AUT2 to MNTB neurons from brain slices of either WT or Fmr1 ${ }^{-/ y}$ mice (Fig. 6A). Consistent with our previous results, we found that AUT2 compound produced a significant shift of the halfinactivation potential toward hyperpolarization potentials in both genotypes. In Fmr1 ${ }^{-/ y}$ mice, AUT2 shifted $\mathrm{V}_{1 / 2}$ max from $-10.17 \pm 3.82$ to $-35.21 \pm 3.42 \mathrm{mV}\left(p=0.041, t_{(5)}=2.72\right.$, two-tailed paired Student's $t$ test; $n=5, N=5$ animals; Fig.
$6 B, C)$. In WT mice, AUT2 shifted $\mathrm{V}_{1 / 2 \max }$ from $-30.51 \pm 0.37$ to $-44.36 \pm 1.86 \mathrm{mV}\left(p=0.043, t_{(4)}=2.85 ; n=5, N=5\right.$ animals two-tailed paired Student's $t$ test; Fig. $6 D$ ).

To exclude the possibility that AUT2 may have affected other type of channels in MNTB neurons, we repeated the experiments described in Figure 5 in the presence of a low concentration of tetraethylammonium (TEA; $1 \mathrm{~mm}$ ), which selectively eliminates the component of current carried by Kv3 channels in these cells (Wang et al., 1998a). We found that, in the presence of TEA, AUT2 did not change the magnitude or the voltage dependence of either low- or high-threshold $\mathrm{K}^{+}$currents when tested in both 
WT and $F m r 1^{-l y}$ mice. Using a two-way ANOVA (with Bonferroni's post hoc) to analyze the effect of AUT2 on the amplitude of both high- and low-threshold potassium currents, we found no significant effect in WT mice (high $K v: F_{(1,60)}=2.32, p=0.13$; low $K v: F_{(1,102)}=4.07, p=0.35$; Figure $7 A, B$, middle panels). AUT2 also failed to change the amplitude of potassium currents in $F m r 1^{-/ y}$ mice (high $K v: F_{(1,26)}=0.99, p=0.32$; low $K v: F_{(1,102)}$ $=1.77, p=0.18$; Figure $7 C, D$, middle panels). When the normalized conductance of the high-threshold currents in WT mice was plotted as a function of membrane voltage, there was no significant shift of the $\mathrm{V}_{1 / 2}$ after AUT2 treatment $(10 \mu \mathrm{M}): \mathrm{V}_{1 / 2}$ was $10.11 \pm 6.30 \mathrm{mV}$ and changed to $5.2 \pm 5.4$ after AUT2 application ( $p=0.42, n=3, N=3$ animals, Student's paired $t$ test; Fig. $7 A$, right). Similarly, AUT2 failed to change the voltage dependence of activation of low-threshold $\mathrm{K}^{+}$currents in the presence of TEA ( $\mathrm{V}_{1 / 2 \text { max }}$ for WT mice before AUT2 was $8.52 \pm$ $0.8 \mathrm{mV}$ and $5.40 \pm 1.07 \mathrm{mV}$ after AUT2 application; $p=0.09$, $n=3, N=3$ animals, paired $t$ test; Fig. $7 B$, right).

The conductance of both high- and low-threshold potassium currents in Fmr1 ${ }^{-1 y}$ mice, in the presence of TEA, was also unaffected by AUT2 [ $\mathrm{V}_{1 / 2 \text { max }}$ for high-threshold currents: $9.42 \pm 0.40$ $\mathrm{mV}$ before AUT2; $4.82 \pm 0.63 \mathrm{mV}$ after AUT2; $p=0.12, n=4$, $N=4$ animals, Student's paired $t$ test (Fig. $7 C$, right); $\mathrm{V}_{1 / 2 \max }$ for low-threshold currents: $10.00 \pm 1.72 \mathrm{mV}$ before AUT2; $5.16 \pm$ $0.35 \mathrm{mV}$ after AUT2; $p=0.36, n=4, N=4$ animals, Student's paired $t$ test (Fig. $7 D$, right)].

These changes in amplitude and voltage dependence of the high- and low-threshold currents in normal conditions and the absence of these changes in the presence of the selective inhibitor of Kv3 channels (TEA) are entirely consistent with that expected from the effects of AUT2 observed on recombinant human Kv3.1 currents in transfected cells (Brown et al., 2016). A shift in steadystate inactivation to more negative potentials would be expected to reduce maximal currents evoked by the high-threshold voltage protocol. With the more negative holding potential, however, the shift in activation of Kv3.1 to more negative potentials would be expected to increase evoked currents, particularly at those negative test potentials where Kv3.1 channels are not normally activated.

\section{AUT2 reduces the hyperexcitability of MNTB neurons in Fmr1 ${ }^{-/ y}$ mice}

The effects of AUT2 on high- and low-threshold components of $\mathrm{K}^{+}$currents are directly opposite to those produced by loss of FMRP (Fig. 4). In particular, the increase in current that activates close to the resting potential would be expected to limit the generation of action potentials by increasing spike threshold. We therefore performed current-clamp recordings of MNTB neurons from $\mathrm{Fmrl}^{-/ y}$ mice to determine the effects of AUT2 on their firing patterns evoked by repetitive stimulation with brief current pulses ( $1 \mathrm{nA}, 0.3 \mathrm{~ms}, 20$ stimuli) applied at rates from 50 to $300 \mathrm{~Hz}$ (Fig. 8). We found that AUT2 $(10 \mu \mathrm{M})$ decreased the number of action potentials of MNTB neurons at all frequencies tested. Using two-way ANOVA and the Holm-Sidak method for post hoc correction, we found that the effect of AUT2 treatment was significant $\left(F_{(1,14)}=29.32, p<0.0001\right)$ and that AUT2 decreased the number of spikes at all stimulus frequencies tested (50 $\mathrm{Hz}: p=0.002 ; 200 \mathrm{~Hz}: p=0.02$; and $300 \mathrm{~Hz}: p=0.0006$, HolmSidak method; Fig. $8 A, B)$.

\section{AUT2 rescues the ABR of $F m r 1^{-/ y}$ mice}

Because AUT2 reversed some of the effects of loss of FMRP on $\mathrm{K}^{+}$currents and firing patterns of MNTB neurons in brainstem slices, we tested the effects of AUT2 on auditory function in Fmr1 ${ }^{-/ y}$ mice in vivo. As shown in Figure 1, the magnitude of wave IV of the ABR of 15-d-old mice was significantly enhanced in $F m r 1^{-l y}$ animals compared with wild-type mice of the same age, which is consistent with the increased excitability of MNTB neurons. We found that intraperitoneal administration of AUT2 (30 mg/kg, $20 \mathrm{~min}$ before testing) significantly reduced the magnitude of wave IV in five of five mice without changing the magnitude of wave I (Fig. 9A,B). For sounds delivered at $80 \mathrm{~dB}$, the amplitude of wave IV decreased from $1.24 \pm 0.10$ to $0.9 \pm 0.07$ $\mu \mathrm{V}$ after AUT2 treatment ( $p=0.001$, two-way ANOVA; $N=5$ Fmr1 ${ }^{-1 y}$ mice) without changing the ABR threshold. The twoway ANOVA revealed no significant interaction between wave IV amplitudes before and after AUT2 treatment with the intensity of sound level $\left(F_{(5,59)}=0.478, p=0.8\right)$. We found, however, a significant difference in the effect of sound level on wave IV amplitude before and after AUT2 $\left(F_{(1,59)}=11.26, p=0.001\right)$.

AUT2 failed to change the magnitude of wave I $(p=0.3$, two-way ANOVA). Although AUT2 slightly increased the latency of wave I at 80 and $90 \mathrm{~dB}$, this effect was not statistically significant ( $p=0.1$, two-way ANOVA with multiple comparisons using the Holm-Sidak method; Fig. $9 B$ ). When the vehicle was administered alone (without AUT2) in another group of mice, the magnitudes of wave I and IV were unchanged. For example, at a sound level of $85 \mathrm{~dB}$, the amplitude of wave IV was $1.78 \pm 0.57$ $\mu \mathrm{V}$ in $\mathrm{Fmrl}^{-1 y}$ mice before the administration of the vehicle compared with $1.52 \pm 0.64 \mu \mathrm{V} 20 \mathrm{~min}$ after the vehicle administration ( $N=4$ animals; $p=0.99$, two-way ANOVA; Fig. $10 A)$. At the same sound level, the administration of the vehicle to Fmr1 ${ }^{-/ y}$ mice did not change the amplitude of wave I (before vehicle: $2.00 \pm 0.49 \mu \mathrm{V}$; vs after vehicle: $1.90 \pm 0.45 \mu \mathrm{V} ; N=4$ animals; $p=0.99$, two-way ANOVA; Fig. 10A). Similarly, the latencies of waves I and IV were also unchanged by the administration of the vehicle. At a sound level of $85 \mathrm{~dB}$, the latency of wave I was $2.42 \pm 0.28 \mathrm{~ms}$ before and $2.55 \pm 0.23 \mathrm{~ms}$ after vehicle administration and the latency of wave IV was $6.47 \pm 0.30 \mathrm{~ms}$ before and $6.072 \pm 0.238 \mathrm{~ms}$ after the administration of vehicle $(N=4$ animals; $p=0.98$ and $p=0.90$, respectively, two-way ANOVA; Fig. 10A).

We also tested the effect of AUT2 on wild-type mice and found no significant changes in the amplitude of waves I or IV, perhaps because levels of Kv3.1 are lower in wild-type mice (Fig. $10 B, C)$. Together, these data suggest that AUT2 rescues the auditory function of $F m r 1^{-/ y}$ mice by changing the voltage dependence of Kv3-like, high-threshold $\mathrm{K}^{+}$channels, thereby reducing excitability and restoring brainstem responses in vivo to those of wild-type animals.

\section{Discussion}

Our findings suggest that one mechanism by which the loss of FMRP alters the processing of auditory information is by altering the expression and activity of $\mathrm{K}^{+}$channels. Our results with Fmr1 ${ }^{-/ y}$ mice are consistent with the clinical observation that patients with fragile $\mathrm{X}$ syndrome experience a hypersensitivity to sound and impairment of auditory processing (St Clair et al., 1987; Arinami et al., 1988; Ferri, 1989; Wisniewski et al., 1991; Rojas et al., 2001; Castrén et al., 2003; Van der Molen et al., 2012; Garcia-Pino et al., 2017). Most of these studies show a prolonged latency of the ABR response in humans, particularly for waves III and $\mathrm{V}$ and for interpeak intervals III-V and $\mathrm{I}-\mathrm{V}$, suggesting a central, as opposed to a peripheral, dysfunction of auditory pathways (Arinami et al., 1988). Consistent with these findings, the marked increase in the magnitude of wave IV in $\mathrm{Fmrl}^{-/ y}$ mice in 
A

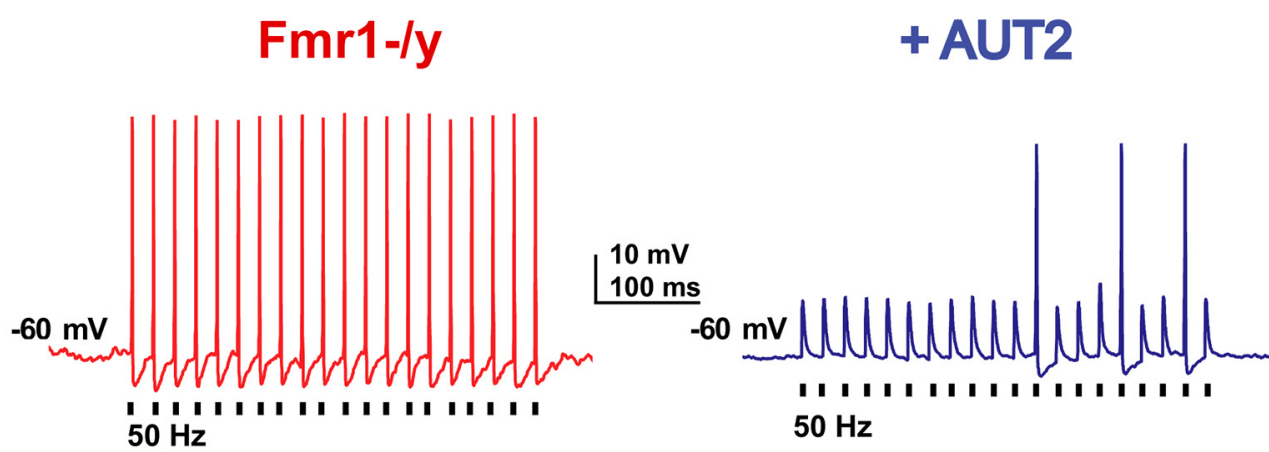

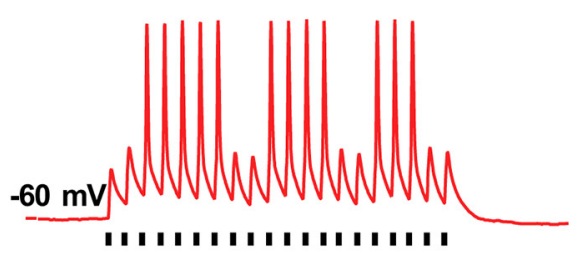

$200 \mathrm{~Hz}$

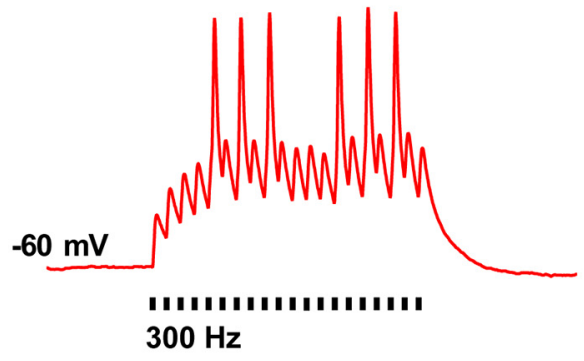

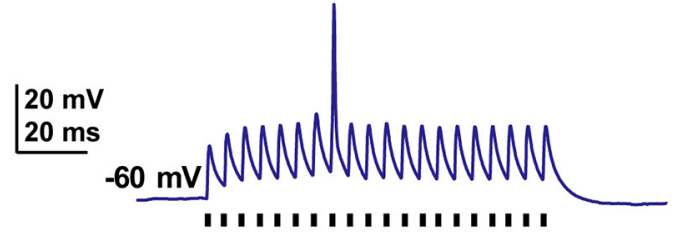

$200 \mathrm{~Hz}$

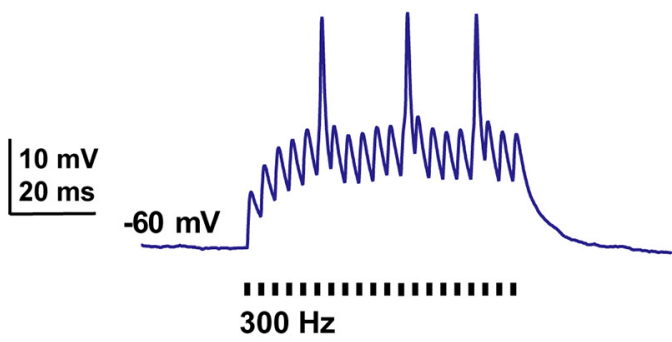

B
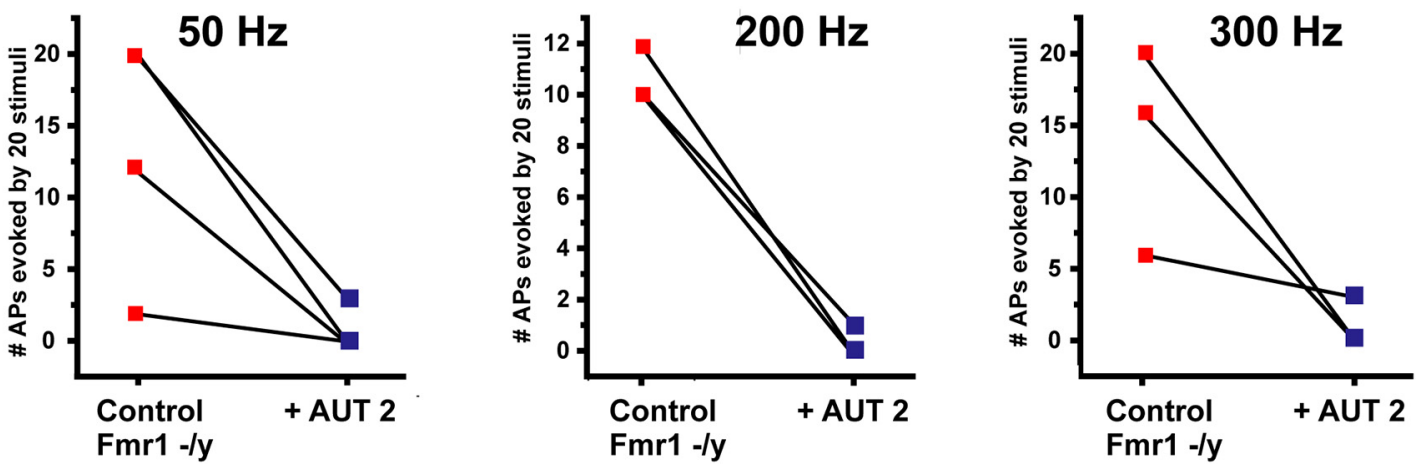

Figure 8. AUT2 reduces the firing rate of MNTB neurons of $F m r 1^{-1 y}$ mice. $A$, Current-clamp recordings of action potentials evoked by 20 consecutive stimuli of intracellular current pulses ( $2 \mathrm{nA}$, $0.3 \mathrm{~ms}$ ) in MNTB neurons applied at 50,200 , or $300 \mathrm{~Hz}$ before and after application of AUT2 $(10 \mu \mathrm{M})$. B, Plots of the numbers of action potentials evoked by repetitive stimulation at 50,200 , and 300 $\mathrm{Hz}$ in different experiments before and after AUT2 application. AUT2 decreased the number of evoked action potentials in MNTB neurons at all frequencies tested $(n=3, N=3$ animals; $p<0.0001$, two-way ANOVA followed by Holm-Sidak post-test).

the present study also suggests that changes in the excitability of brainstem nuclei are more pronounced than those in auditory afferents as there is little or no change in wave I amplitude compared with that of wave IV.

We have demonstrated that in neurons of the MNTB in Fmr1 ${ }^{-l y}$ mice, low-threshold $\mathrm{K}^{+}$currents, which activate near the resting potential, are significantly decreased. The $\mathrm{K}^{+}$channels that contribute to these currents in the MNTB of mice have been identified, and include Kv1.1, Kv1.2, Kv1.6, Kv11.1, Kv11.3, $\mathrm{K}_{\mathrm{Na}} 1.1$, and $\mathrm{K}_{\mathrm{Na}} 1.2$ channel subunits (Dodson et al., 2002; Brew et al., 2003; Kopp-Scheinpflug et al., 2003; Yang et al., 2007;
Hardman and Forsythe, 2009; Brown et al., 2010). In the neurons of wild-type mice, these channels, particularly Kv1.1. and Kv1.2, serve to limit the response to sustained depolarization to a single action potential at the onset of the depolarization. A reduction in the low-threshold $\mathrm{K}^{+}$current is therefore consistent with the repetitive firing of MNTB neurons of $F m r 1^{-1 y}$ mice evoked by depolarization. The mRNA for three of the low-threshold $\mathrm{K}^{+}$ subunits are targets of FMRP (Darnell et al., 2011). Moreover, two of these subunits, $\mathrm{K}_{\mathrm{Na}} 1.1$ (Slack) and Kv1.2, directly bind FMRP itself (Brown et al., 2010; Zhang et al., 2012; Yang et al., 2018). In MNTB neurons, the Slack-FMRP interaction stimulates 


\section{$\mathrm{Fmr1}^{-/ \mathrm{y}}$}

A

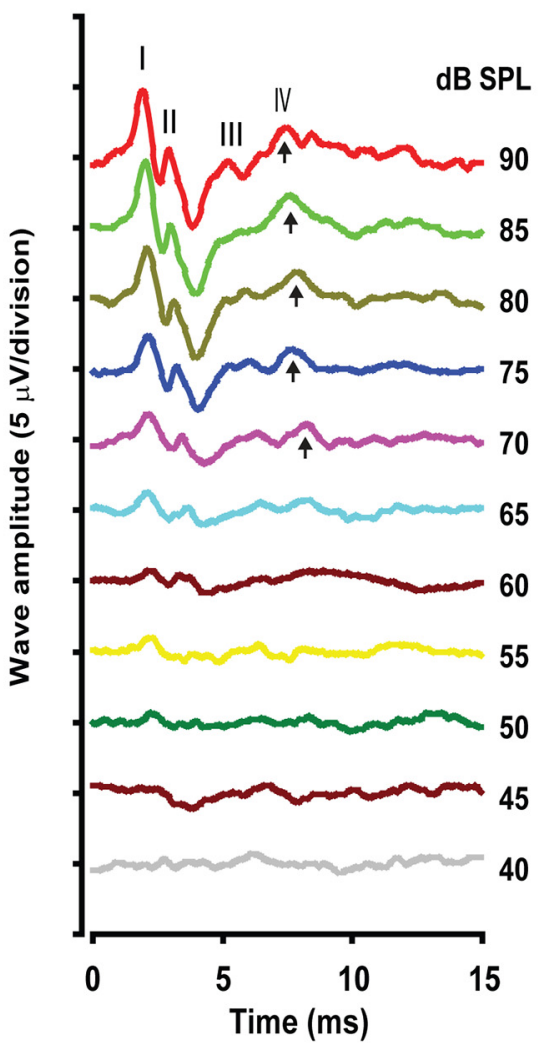

B
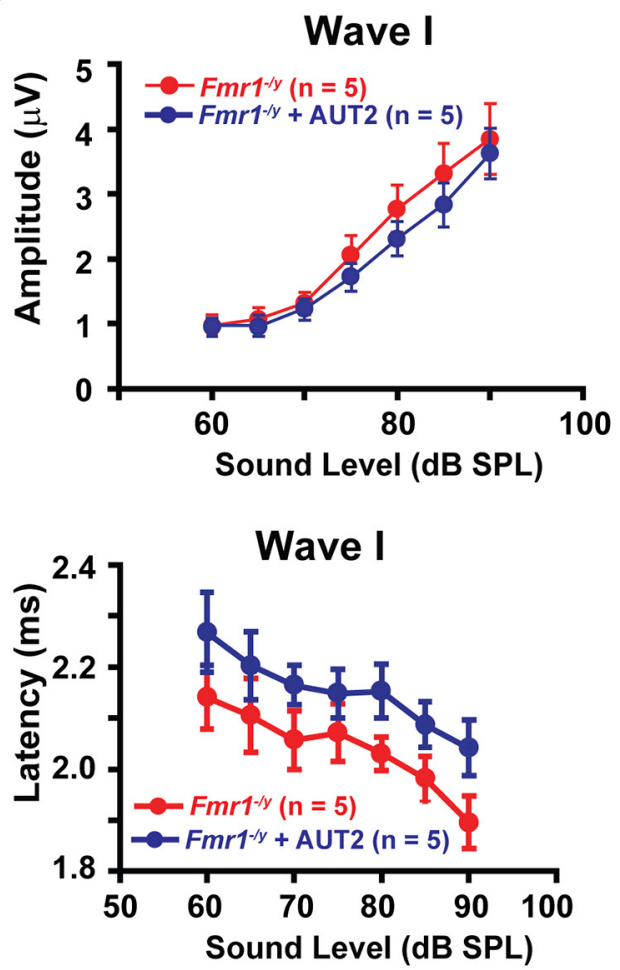

\section{$F m r 1^{-/ y}+$ AUT2}

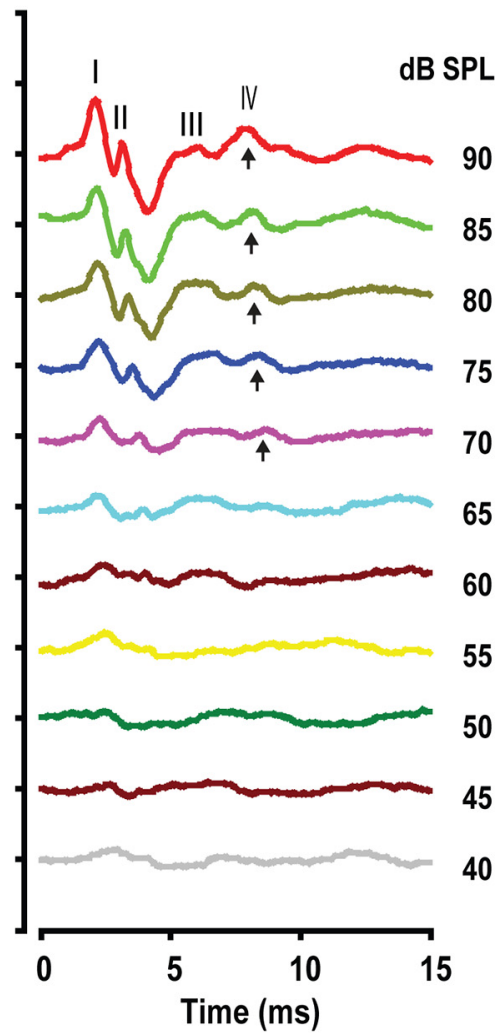

Wave IV

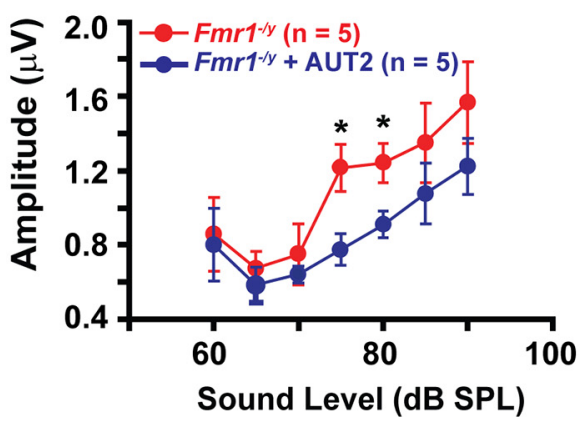

Wave IV

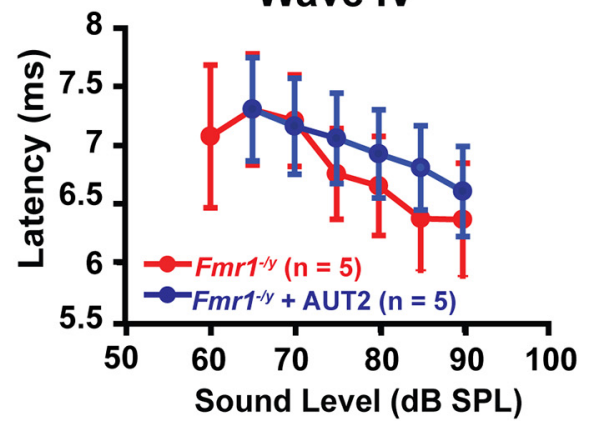

Figure 9. AUT2 rescues the auditory function of $F m r 1^{-1 y}$ mice. $A$, Representative ABR traces recorded from $F m r 1^{-/ y}$ mice before and 20 min after intraperitoneal injection of AUT2 ( $30 \mathrm{mg} / \mathrm{kg}$ ). Arrows indicate wave IV of the ABR response. $B$, Plots of the amplitudes and latencies of ABR waves I and IV as a function of sound level before and after injection of AUT2. The group data show a significant decrease in the amplitude of ABR wave IV after AUT2 injection $(p=0.001)$ with no change in the amplitude of wave I $(p=0.3)$. In $B$, asterisks indicate statistical significance (two-way ANOVA followed by Holm-Sidak post-test). 
A
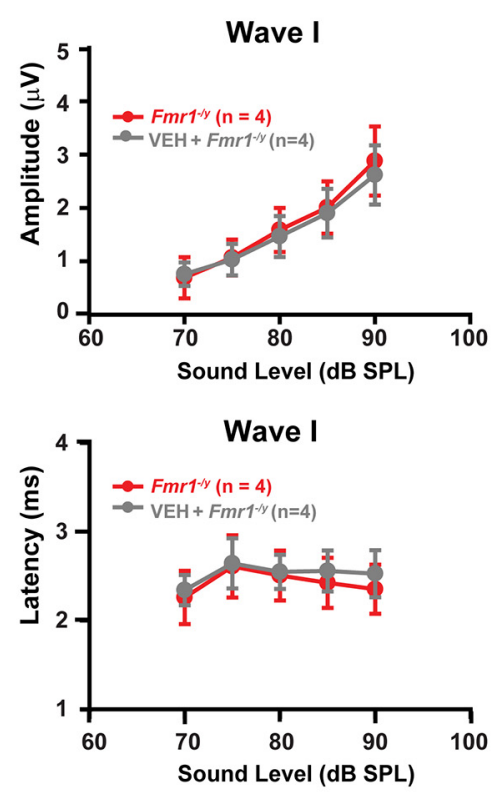

B
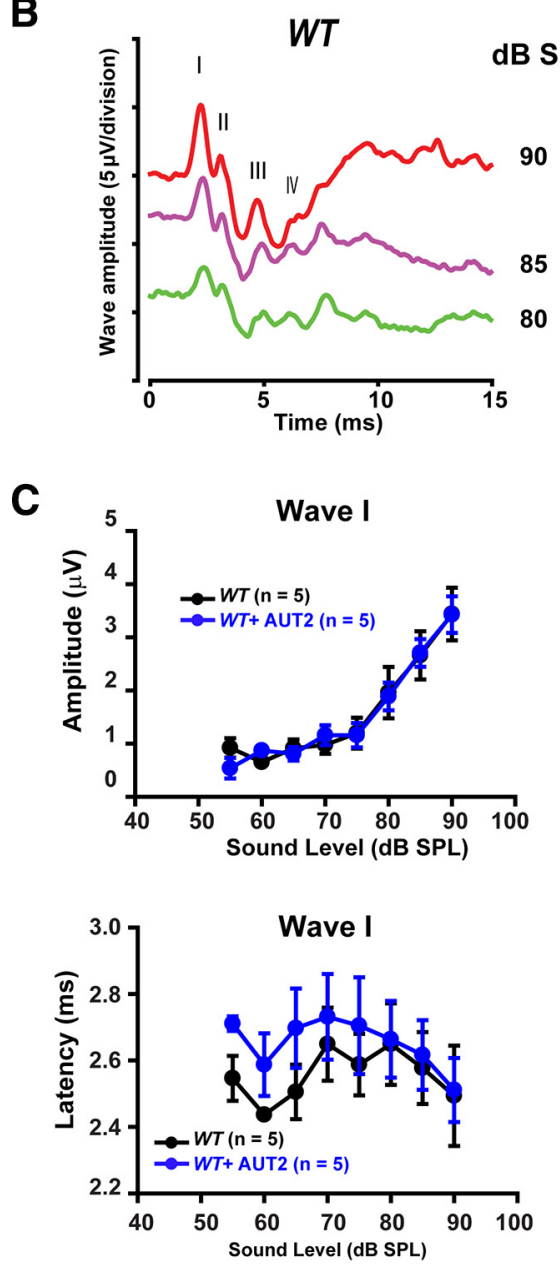
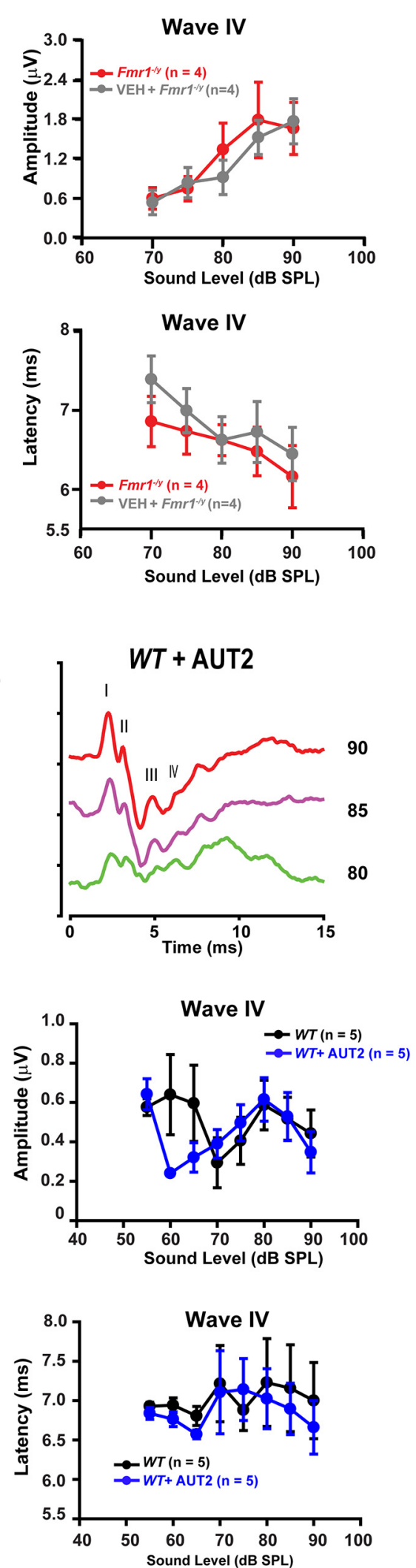

channel activity, and the $\mathrm{Na}^{+}$-dependent $\mathrm{K}^{+}$current is reduced in these neurons in $\mathrm{Fmrl}^{-1 y}$ mice (Brown et al., 2010). Such a reduction in $\mathrm{K}_{\mathrm{Na}}$ current is expected to reduce the temporal accuracy of firing (Yang et al., 2007).

Our findings also indicate that, in contrast to the low-threshold currents, highthreshold $\mathrm{K}^{+}$currents are enhanced in the MNTB of $\mathrm{Fmrl}^{-/ y}$ mice relative to those in wild-type animals. The dominant channel responsible for the highthreshold current in MNTB neurons is $\mathrm{Kv} 3.1 \mathrm{~b}$, and this current is reduced by $>80 \%$ in $\mathrm{Kv} 3.1^{-1-}$ mice (Wang et al., 1998a; Macica et al., 2003). Our present recordings are also consistent with this identification in that Kv3.1 currents can have a phase of rapid partial inactivation that was also seen in many of the present recordings of high-threshold current. This transient component can be detected in some but not all Kv3.1-expressing transfected cells and in native neurons (Critz et al., 1993; Kanemasa et al., 1995; Wang et al., 1998b; McCrossan et al., 2003). The transient component, which is regulated by auxiliary subunits, can be attributed, at least in part, to the rapid accumulation of external $\mathrm{K}^{+}$ions (Critz et al., 1993; Wang et al., 1998b; McCrossan et al., 2003). Nevertheless, although Kv3.1 appears to be the dominant channel contributing to high-threshold currents, Kv2.2 can be become the dominant subunit responsible for action potential repolarization with stimulation at low rates (Steinert et al., 2008, 2011).

Numerous studies have demonstrated that Kv3.1 channels promote the ability of neurons to fire at high rates (Rudy and McBain, 2001; Gu et al., 2012; Kaczmarek and Zhang, 2017). mRNA for Kv3.1 was one of the first mRNAs to be recognized as a target of FMRP (Darnell et al., 2001; Strumbos et al., 2010b; Darnell et al., 2011), and our present findings are consistent with those of previous studies demonstrating that Kv3.1 currents are enhanced in Fmr1 ${ }^{-/ y}$ mice (Strumbos et al., 2010b). Another possibility is that Kv3.4 channels, which are located both presynaptically and postsynaptically in the brainstem region (Brooke et al., 2004) may contribute to the hyperexcitability of MNTB neurons in Fmr1 ${ }^{-1 y}$ mice either by

Figure 10. Administration of vehicle does not alter ABR waves in $\mathrm{Fmr}^{-1 /}$ mice, and AUT2 does not alter auditory function in wild-type mice. $A$, Plots of the amplitudes and latencies of ABR waves I and IV as a function of sound level before and after the administration of vehicle to $F m r 1^{-1 /}$ mice. No statistical differences in the magnitude of wave I and IV ( $p=0.99$ for both) or in the latencies of wave I and IV ( $p=0.98$ and $p=0.90$, respectively) were found after vehicle injection (two-way ANOVA followed by Holm-Sidak post-test). $\boldsymbol{B}$, Representative ABR traces recorded from WT mice before and $20 \mathrm{~min}$ after intraperitoneal injection of AUT2 $(30 \mathrm{mg} / \mathrm{kg})$. Traces represent responses to sounds delivered at 80,85 , and $90 \mathrm{~dB}$. C, Plots of the amplitudes and latencies of ABR waves I and IV as a function of sound level before and after injection of AUT2. The group data show no significant changes in

\section{$\leftarrow$}

the amplitude of ABR waves I and IV $(p=0.92, p=0.3$ respectively) after AUT2 injection. Similarly, AUT2 did not change the latencies of waves I and IV ( $p=0.8$ and $p=0.46$, respectively, two-way ANOVA by Holm-Sidak post-test). 
speeding the repolarization rate of action potentials or by enhancing glutamatergic synaptic transmission (Muqeem et al., 2018).

Our studies were performed using 15-d old mice. This allows a direct comparison of ABR responses in vivo with recordings of $\mathrm{K}^{+}$currents in MNTB neurons from brainstem slices before the onset of myelination, which hampers patch-clamp recordings at later stages. We found no change in the ABR threshold in the Fmr1 ${ }^{-/ y}$ mice but did find an increase in the magnitude of wave IV, a finding consistent with the increase in the intrinsic excitability of different types of brainstem and midbrain nuclei, particularly the MNTB. ABR recordings reflect the passage of auditory information along diverse anatomical pathways, and the high- and low-threshold potassium channels studied here are widely expressed in cells of the auditory system. Thus, it is possible that changes in the amplitude of wave IV captured in this study may result from increased excitability or synchrony in other nuclei such as the inferior colliculus, and the medial and/or lateral superior olive.

We also found that, in $F m r 1^{-1 y}$ mice, the magnitude of wave I was decreased at higher sound levels (85-90 dB), further reinforcing the concept that auditory hyperexcitability in fragile $\mathrm{X}$ syndrome results from changes in central rather than peripheral pathways. Another study of $F m r 1^{-/ y}$ mice, which used adult animals, found an imbalance of glutamatergic and GABAergic inputs within the MNTB (Rotschafer et al., 2015; McCullagh et al., 2017). This study, however, also found a different pattern of changes in the ABR, specifically that while the amplitudes of the early waves I and III were reduced, the later waves IV and V were unchanged. This apparent discrepancy may reflect adaptive changes that occur during early life. Both the ABR waveform threshold and latency are subject to changes during development (Song et al., 2006). Moreover, it has been established that, at least for Kv3.1 channels, the maintenance of channel expression is very markedly altered by ongoing auditory activity (von Hehn et al., 2004; Leão et al., 2010; Strumbos et al., 2010a,b). Thus, our present findings are most likely to be relevant to the effects of the loss of FMRP early in development.

We found that the imbalance of low- to high-threshold $\mathrm{K}^{+}$ currents in MNTB neurons of $F m r 1^{-/ y}$ mice could, in large part, be corrected by treatment with AUT2, a modulator of Kv3 family channels. AUT2 is one of a number of agents that have been found to shift the voltage dependence of activation of Kv3.1 and Kv3.2 channels to more negative potentials, increasing the amount of $\mathrm{K}^{+}$current activated by depolarization to voltages closer to the resting potential (Rosato-Siri et al., 2015; Taskin et al., 2015; Brown et al., 2016; Boddum et al., 2017). AUT2 also produces a negative shift in the voltage dependence of steadystate inactivation, reducing the amount of current activated by depolarizations to more positive membrane potential (e.g., +30 $\mathrm{mV})$. A consequence of this is to reduce high-voltage activated $\mathrm{K}^{+}$current. These changes also reduce the firing rate of MNTB neurons in wild-type mice (Brown et al., 2016). Thus, AUT2 appears to reduce the intrinsic excitability of MNTB neurons by increasing the low-threshold component and reducing the highthreshold component of $\mathrm{K}^{+}$currents. The finding that AUT2 normalizes ABR responses in $\mathrm{Fmrl}^{-/ y}$ mice in vivo is therefore consistent with the suggestion that the enhancement of wave IV in $F m r 1^{-/ y}$ animals reflects increased intrinsic excitability of auditory brainstem neurons. It is possible, however, that AUT2 has additional biophysical effects that have not been captured in the present analyses.
Increased neuronal excitability is detected in a variety of brain regions in $\mathrm{Fmrl}^{-/ y}$ mice, including the auditory cortex and the lateral superior olive (Kim et al., 2013; Rotschafer and Razak, 2014; Garcia-Pino et al., 2017), as well as the barrel and prefrontal cortex (Zhang et al., 2012, 2014; Gonçalves et al., 2013; Hébert et al., 2014; Kalmbach et al., 2015; Deng and Klyachko, 2016a,b). In some of these areas, alterations in $\mathrm{K}^{+}$channels such as Kv1.2, $\mathrm{Kv} 4.2$, and $\mathrm{K}_{\mathrm{Ca}} 1.1$ (BK) have been implicated in the hyperexcitability of fragile X mice (Zhang et al., 2014; Kalmbach et al., 2015). The function and/or the expression of these channels is regulated by FMRP either through mRNA binding or through protein-protein interactions with the channels themselves. (Frick et al., 2017). Given the large number of FMRP targets that control multiple aspects of neuronal function, including synaptic transmission, signal transduction, and neuronal development, it is likely that multiple therapeutic strategies will be required to reduce the broad range of symptoms of patients with fragile $\mathrm{X}$ syndrome. However, our results suggest that the hypersensitivity to sound observed in a large proportion of patients with FXS may be ameliorated by drugs that modulate Kv3.1 channels.

\section{References}

Akil O, Oursler AE, Fan K, Lustig LR (2016) Mouse auditory brainstem response testing. Bio Protoc 6:e1768

Aloisi E, Le Corf K, Dupuis J, Zhang P, Ginger M, Labrousse V, Spatuzza M, Georg Haberl M, Costa L, Shigemoto R, Tappe-Theodor A, Drago F, Vincenzo Piazza P, Mulle C, Groc L, Ciranna L, Catania MV, Frick A (2017) Altered surface mGluR5 dynamics provoke synaptic NMDAR dysfunction and cognitive defects in Fmr1 knockout mice. Nat Commun $8: 1103$.

Arinami T, Sato M, Nakajima S, Kondo I (1988) Auditory brain-stem responses in the fragile X syndrome. Am J Hum Genet 43:46-51.

Bhattacharjee A, Gan L, Kaczmarek LK (2002) Localization of the Slack potassium channel in the rat central nervous system. J Comp Neurol 454: 241-254.

Bhattacharjee A, von Hehn CA, Mei X, Kaczmarek LK (2005) Localization of the $\mathrm{Na}+$-activated $\mathrm{K}+$ channel Slick in the rat central nervous system. J Comp Neurol 484:80-92.

Boddum K, Hougaard C, Xiao-Ying Lin J, von Schoubye NL, Jensen HS, Grunnet M, Jespersen T (2017) Kv3.1/Kv3.2 channel positive modulators enable faster activating kinetics and increase firing frequency in fastspiking GABAergic interneurons. Neuropharmacology 118:102-112.

Bostrom C, Yau SY, Majaess N, Vetrici M, Gil-Mohapel J, Christie BR (2016) Hippocampal dysfunction and cognitive impairment in fragile-X syndrome. Neurosci Biobehav Rev 68:563-574.

Brager DH, Johnston D (2014) Channelopathies and dendritic dysfunction in fragile X syndrome. Brain Res Bull 103:11-17.

Brew HM, Forsythe ID (1995) Two voltage-dependent $\mathrm{K}^{+}$conductances with complementary functions in postsynaptic integration at a central auditory synapse. J Neurosci 15:8011-8022.

Brew HM, Forsythe ID (2005) Systematic variation of potassium current amplitudes across the tonotopic axis of the rat medial nucleus of the trapezoid body. Hear Res 206:116-132.

Brew HM, Hallows JL, Tempel BL (2003) Hyperexcitability and reduced low threshold potassium currents in auditory neurons of mice lacking the channel subunit Kv1.1. J Physiol 548:1-20.

Brooke RE, Atkinson L, Batten TF, Deuchars SA, Deuchars J (2004) Association of potassium channel Kv3.4 subunits with pre- and post-synaptic structures in brainstem and spinal cord. Neuroscience 126:1001-1010.

Brown MR, Kronengold J, Gazula VR, Chen Y, Strumbos JG, Sigworth FJ, Navaratnam D, Kaczmarek LK (2010) Fragile X mental retardation protein controls gating of the sodium-activated potassium channel slack. Nat Neurosci 13:819-821.

Brown MR, El-Hassar L, Zhang Y, Alvaro G, Large CH, Kaczmarek LK (2016) Physiological modulators of Kv3.1 channels adjust firing patterns of auditory brain stem neurons. J Neurophysiol 116:106-121.

Castrén M, Pääkkönen A, Tarkka IM, Ryynänen M, Partanen J (2003) Augmentation of auditory $\mathrm{N} 1$ in children with fragile X syndrome. Brain Topogr 15:165-171. 
Chonchaiya W, Schneider A, Hagerman RJ (2009) Fragile X: a family of disorders. Adv Pediatr 56:165-186.

Critz SD, Wible BA, Lopez HS, Brown AM (1993) Stable expression and regulation of a rat brain K+ channel. J Neurochem 60:1175-1178.

Curia G, Gualtieri F, Bartolomeo R, Vezzali R, Biagini G (2013) Resilience to audiogenic seizures is associated with p-ERK1/2 dephosphorylation in the subiculum of Fmr1 knockout mice. Front Cell Neurosci 7:46.

Darnell JC, Jensen KB, Jin P, Brown V, Warren ST, Darnell RB (2001) Fragile X mental retardation protein targets $\mathrm{G}$ quartet mRNAs important for neuronal function. Cell 107:489-499.

Darnell JC, Van Driesche SJ, Zhang C, Hung KY, Mele A, Fraser CE, Stone EF, Chen C, Fak JJ, Chi SW, Licatalosi DD, Richter JD, Darnell RB (2011) FMRP stalls ribosomal translocation on mRNAs linked to synaptic function and autism. Cell 146:247-261.

Deng PY, Klyachko VA (2016a) Increased persistent sodium current causes neuronal hyperexcitability in the entorhinal cortex of Fmr1 knockout mice. Cell Rep 16:3157-3166.

Deng PY, Klyachko VA (2016b) Genetic upregulation of BK channel activity normalizes multiple synaptic and circuit defects in a mouse model of fragile X syndrome. J Physiol 594:83-97.

Deng PY, Rotman Z, Blundon JA, Cho Y, Cui J, Cavalli V, Zakharenko SS, Klyachko VA (2013) FMRP regulates neurotransmitter release and synaptic information transmission by modulating action potential duration via BK channels. Neuron 77:696-711.

Deng PY, Carlin D, Mi Oh YM, Myrick LK, Warren ST, Cavalli V, Klyachko VA (2019) Voltage-independent SK-channel dysfunction causes neuronal hyperexcitability in the hippocampus of Fmr1 knock-out mice. J Neurosci 39:28-43.

Dodson PD, Barker MC, Forsythe ID (2002) Two heteromeric Kv1 potassium channels differentially regulate action potential firing. J Neurosci 22:6953-6961.

Ferri R (1989) Brain-stem auditory evoked potentials in the fragile X syndrome. Am J Hum Genet 45:977-979.

Ferron L, Nieto-Rostro M, Cassidy JS, Dolphin AC (2014) Fragile X mental retardation protein controls synaptic vesicle exocytosis by modulating N-type calcium channel density. Nat Commun 5:3628.

Frick A, Ginger M, El-Hassar L, Kaczmarek L (2017) Ion channel dysfunction and FXS. In: Fragile X syndrome: from genetics to targeted treatment (Willemsen R, Kooy RF, eds), pp 323-340. London: Academic.

Gan L, Kaczmarek LK (1998) When, where, and how much? expression of the Kv3.1 potassium channel in high-frequency firing neurons. J Neurobiol 37:69-79.

Garber KB, Visootsak J, Warren ST (2008) Fragile X syndrome. Eur J Hum Genet 16:666-672.

Garcia-Pino E, Gessele N, Koch U (2017) Enhanced excitatory connectivity and disturbed sound processing in the auditory brainstem of fragile $\mathrm{X}$ mice. J Neurosci 37:7403-7419.

Gonçalves JT, Anstey JE, Golshani P, Portera-Cailliau C (2013) Circuit level defects in the developing neocortex of fragile X mice. Nat Neurosci 16: 903-909.

Grigg JJ, Brew HM, Tempel BL (2000) Differential expression of voltagegated potassium channel genes in auditory nuclei of the mouse brainstem. Hear Res 140:77-90.

Gu Y, Barry J, McDougel R, Terman D, Gu C (2012) Alternative splicing regulates kv3.1 polarized targeting to adjust maximal spiking frequency. J Biol Chem 287:1755-1769.

Hall SS, Walter E, Sherman E, Hoeft F, Reiss AL (2009) The neural basis of auditory temporal discrimination in girls with fragile $\mathrm{X}$ syndrome. J Neurodev Disord 1:91-99.

Hardman RM, Forsythe ID (2009) Ether-a-go-go-related gene K+ channels contribute to threshold excitability of mouse auditory brainstem neurons. J Physiol 587:2487-2497.

Hébert B, Pietropaolo S, Même S, Laudier B, Laugeray A, Doisne N, Quartier A, Lefeuvre S, Got L, Cahard D, Laumonnier F, Crusio WE, Pichon J, Menuet A, Perche O, Briault S (2014) Rescue of fragile X syndrome phenotypes in Fmrl KO mice by a BKCa channel opener molecule. Orphanet J Rare Dis 9:124.

Jewett DL, Williston JS (1971) Auditory-evoked far fields averaged from the scalp of humans. Brain 94:681-696.

Kaczmarek LK, Zhang Y (2017) Kv3 channels: enablers of rapid firing, neurotransmitter release, and neuronal endurance. Physiol Rev 97:14311468 .
Kalmbach BE, Johnston D, Brager DH (2015) Cell-type specific channelopathies in the prefrontal cortex of the fmr1-/y mouse model of fragile $\mathrm{X}$ syndrome. eNeuro 2:ENEURO.0114-15.2015.

Kanemasa T, Gan L, Perney TM, Wang LY, Kaczmarek LK (1995) Electrophysiological and pharmacological characterization of a mammalian shaw channel expressed in NIH 3T3 fibroblasts. J Neurophysiol 74:207217.

Kim H, Gibboni R, Kirkhart C, Bao S (2013) Impaired critical period plasticity in primary auditory cortex of fragile X model mice. J Neurosci 33:15686-15692.

Kopp-Scheinpflug C, Fuchs K, Lippe WR, Tempel BL, Rübsamen R (2003) Decreased temporal precision of auditory signaling in Kcna1-null mice: an electrophysiological study in vivo. J Neurosci 23:9199-9207.

Kopp-Scheinpflug C, Steinert JR, Forsythe ID (2011) Modulation and control of synaptic transmission across the MNTB. Hear Res 279:22-31.

Leão KE, Leão RN, Deardorff AS, Garrett A, Fyffe R, Walmsley B (2010) Sound stimulation modulates high-threshold $\mathrm{K}+$ currents in mouse auditory brainstem neurons. Eur J Neurosci 32:1658-1667.

Li W, Kaczmarek LK, Perney TM (2001) Localization of two high-threshold potassium channel subunits in the rat central auditory system. J Comp Neurol 437:196-218.

Lozano R, Azarang A, Wilaisakditipakorn T, Hagerman RJ (2016) Fragile X syndrome: A review of clinical management. Intractable Rare Dis Res 5:145-157.

Macica CM, von Hehn CA, Wang LY, Ho CS, Yokoyama S, Joho RH, Kaczmarek LK (2003) Modulation of the Kv3.1b potassium channel isoform adjusts the fidelity of the firing pattern of auditory neurons. J Neurosci 23:1133-1141.

Mathews PJ, Jercog PE, Rinzel J, Scott LL, Golding NL (2010) Control of submillisecond synaptic timing in binaural coincidence detectors by K(v)1 channels. Nat Neurosci 13:601-609.

McCrossan ZA, Lewis A, Panaghie G, Jordan PN, Christini DJ, Lerner DJ, Abbott GW (2003) MinK-related peptide 2 modulates Kv2.1 and Kv3.1 potassium channels in mammalian brain. J Neurosci 23:8077-8091.

McCullagh EA, Salcedo E, Huntsman MM, Klug A (2017) Tonotopic alterations in inhibitory input to the medial nucleus of the trapezoid body in a mouse model of fragile X syndrome. J Comp Neurol 525:3543-3562.

Michalon A, Sidorov M, Ballard TM, Ozmen L, Spooren W, Wettstein JG, Jaeschke G, Bear MF, Lindemann L (2012) Chronic pharmacological mGlu5 inhibition corrects fragile X in adult mice. Neuron 74:49-56.

Muqeem T, Ghosh B, Pinto V, Lepore AC, Covarrubias M (2018) Regulation of nociceptive glutamatergic signaling by presynaptic Kv3.4 channels in the rat spinal dorsal horn. J Neurosci 38:3729-3740.

Myrick LK, Deng PY, Hashimoto H, Oh YM, Cho Y, Poidevin MJ, Suhl JA, Visootsak J, Cavalli V, Jin P, Cheng X, Warren ST, Klyachko VA (2015) Independent role for presynaptic FMRP revealed by an FMR1 missense mutation associated with intellectual disability and seizures. Proc Natl Acad Sci U S A 112:949-956.

Oberlé I, Rousseau F, Heitz D, Kretz C, Devys D, Hanauer A, Boué J, Bertheas MF, Mandel JL (1991) Instability of a 550-base pair DNA segment and abnormal methylation in fragile X syndrome. Science 252:1097-1102.

Pyronneau A, He Q, Hwang JY, Porch M, Contractor A, Zukin RS (2017) Aberrant Racl-cofilin signaling mediates defects in dendritic spines, synaptic function, and sensory perception in fragile X syndrome. Sci Signal 10:eaan0852.

Roberts J, Hennon EA, Anderson K, Roush J, Gravel J, Skinner M, Misenheimer J, Reitz P (2005) Auditory brainstem responses in young males with fragile X syndrome. J Speech Lang Hear Res 48:494-500.

Rojas DC, Benkers TL, Rogers SJ, Teale PD, Reite ML, Hagerman RJ (2001) Auditory evoked magnetic fields in adults with fragile X syndrome. Neuroreport 12:2573-2576.

Rosato-Siri MD, Zambello E, Mutinelli C, Garbati N, Benedetti R, Aldegheri L, Graziani F, Virginio C, Alvaro G, Large CH (2015) A novel modulator of Kv3 potassium channels regulates the firing of parvalbumin-positive cortical interneurons. J Pharmacol Exp Ther 354:251-260.

Rotschafer SE, Razak KA (2014) Auditory processing in fragile $\mathrm{x}$ syndrome. Front Cell Neurosci 8:19.

Rotschafer SE, Marshak S, Cramer KS (2015) Deletion of Fmr1 alters function and synaptic inputs in the auditory brainstem. PLoS One 10: e0117266.

Rudy B, McBain CJ (2001) Kv3 channels: voltage-gated K+ channels designed for high-frequency repetitive firing. Trends Neurosci 24:517-526. 
Sinclair D, Featherstone R, Naschek M, Nam J, Du A, Wright S, Pance K, Melnychenko O, Weger R, Akuzawa S, Matsumoto M, Siegel SJ (2017) GABA-B agonist baclofen normalizes auditory-evoked neural oscillations and behavioral deficits in the Fmr1 knockout mouse model of fragile X syndrome. eNeuro 4:ENEURO.0380-16.2017.

Song L, McGee J, Walsh EJ (2006) Frequency- and level-dependent changes in auditory brainstem responses (ABRS) in developing mice. J Acoust Soc Am 119:2242-2257.

Song P, Yang Y, Barnes-Davies M, Bhattacharjee A, Hamann M, Forsythe ID, Oliver DL, Kaczmarek LK (2005) Acoustic environment determines phosphorylation state of the Kv3.1 potassium channel in auditory neurons. Nat Neurosci 8:1335-1342.

St Clair DM, Blackwood DH, Oliver CJ, Dickens P (1987) P3 abnormality in fragile X syndrome. Biol Psychiatry 22:303-312.

Steinert JR, Kopp-Scheinpflug C, Baker C, Challiss RA, Mistry R, Haustein MD, Griffin SJ, Tong H, Graham BP, Forsythe ID (2008) Nitric oxide is a volume transmitter regulating postsynaptic excitability at a glutamatergic synapse. Neuron 60:642-656.

Steinert JR, Robinson SW, Tong H, Haustein Martin D, Kopp-Scheinpflug C, Forsythe ID (2011) Nitric oxide is an activity-dependent regulator of target neuron intrinsic excitability. Neuron 71:291-305.

Strumbos JG, Polley DB, Kaczmarek LK (2010a) Specific and rapid effects of acoustic stimulation on the tonotopic distribution of Kv3.1b potassium channels in the adult rat. Neuroscience 167:567-572.

Strumbos JG, Brown MR, Kronengold J, Polley DB, Kaczmarek LK (2010b) Fragile $\mathrm{X}$ mental retardation protein is required for rapid experiencedependent regulation of the potassium channel Kv3.1b. J Neurosci 30:10263-10271.

Tan WJT, Song L, Graham M, Schettino A, Navaratnam D, Yarbrough WG, Santos-Sacchi J, Ivanova AV (2017) Novel role of the mitochondrial protein Fus1 in protection from premature hearing loss via regulation of oxidative stress and nutrient and energy sensing pathways in the inner ear. Antioxid Redox Signal 27:489-509.

Taskin B, von Schoubye NL, Sheykhzade M, Bastlund JF, Grunnet M, Jespersen T (2015) Biophysical characterization of KV3.1 potassium channel activating compounds. Eur J Pharmacol 758:164-170.

Van der Molen MJ, Van der Molen MW, Ridderinkhof KR, Hamel BC, Curfs LM, Ramakers GJ (2012) Auditory and visual cortical activity during selective attention in fragile $\mathrm{X}$ syndrome: a cascade of processing deficiencies. Clin Neurophysiol 123:720-729.

Verkerk AJ, Pieretti M, Sutcliffe JS, Fu YH, Kuhl DP, Pizzuti A, Reiner O, Richards S, Victoria MF, Zhang FP (1991) Identification of a gene (FMR-1) containing a CGG repeat coincident with a breakpoint cluster region exhibiting length variation in fragile X syndrome. Cell 65:905914.

von Hehn CA, Bhattacharjee A, Kaczmarek LK (2004) Loss of Kv3.1 tonotopicity and alterations in cAMP response element-binding protein signaling in central auditory neurons of hearing impaired mice. J Neurosci 24:1936-1940.

Wang LY, Gan L, Forsythe ID, Kaczmarek LK (1998a) Contribution of the Kv3.1 potassium channel to high-frequency firing in mouse auditory neurones. J Physiol 509:183-194.

Wang LY, Gan L, Perney TM, Schwartz I, Kaczmarek LK (1998b) Activation of Kv3.1 channels in neuronal spine-like structures may induce local potassium ion depletion. Proc Natl Acad Sci U S A 95:1882-1887.

Wisniewski KE, Segan SM, Miezejeski CM, Sersen EA, Rudelli RD (1991) The $\operatorname{Fra}(\mathrm{X})$ syndrome: neurological, electrophysiological, and neuropathological abnormalities. Am J Med Genet 38:476-480.

Yang B, Desai R, Kaczmarek LK (2007) Slack and Slick K(Na) channels regulate the accuracy of timing of auditory neurons. J Neurosci 27:26172627.

Yang YM, Wang LY (2006) Amplitude and kinetics of action potentialevoked $\mathrm{Ca}^{2+}$ current and its efficacy in triggering transmitter release at the developing calyx of Held synapse. J Neurosci 26:5698-5708.

Yang YM, Arsenault J, Bah A, Krzeminski M, Fekete A, Chao OY, Pacey LK, Wang A, Forman-Kay J, Hampson DR, Wang LY (2018) Identification of a molecular locus for normalizing dysregulated GABA release from interneurons in the Fragile X brain. Mol Psychiatry. Advance online publication. Retrieved April 2, 2019. doi:10.1038/s41380-018-0240-0.

Zhang Y, Brown MR, Hyland C, Chen Y, Kronengold J, Fleming MR, Kohn AB, Moroz LL, Kaczmarek LK (2012) Regulation of neuronal excitability by interaction of fragile $\mathrm{X}$ mental retardation protein with Slack potassium channels. J Neurosci 32:15318-15327.

Zhang Y, Bonnan A, Bony G, Ferezou I, Pietropaolo S, Ginger M, Sans N, Rossier J, Oostra B, LeMasson G, Frick A (2014) Dendritic channelopathies contribute to neocortical and sensory hyperexcitability in Fmr1 ${ }^{(-/ y)}$ mice. Nat Neurosci 17:1701-1709. 